\title{
Cumhuriyet Döneminde Okullarda Askerliğe Hazırlık Kampları Üzerine Bir Sözlü Tarih Çalışması (1935-1947)*
}

\section{An Oral History Study on Preparatory Camps for Military Service in Schools in the Republican Era (1935-1947)}

\author{
Özlem GÜRSOY** (D), Mustafa GÜNDÜZ ${ }^{* * *}$ (1)
}

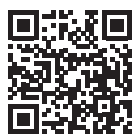

"Bu makale, Prof. Dr. Mustafa Gündüz danışmanlığında Yıldız Teknik Üniversitesi Sosyal Bilimler Enstitüsü'nde hazırlanan "Erken Cumhuriyet Dönemi (1923-1947) Militarist Eğitim: Askerliğe Hazırlık Dersleri ve Askerliğe Hazırlık Kampları" adlı doktora tezinden üretilmiștir.

**Doktora Öğrencisi, Yıldız Teknik

Üniversitesi, Atatürk İlkeleri ve İnkılap Tarihi Bölümü, İstanbul, Türkiye

***Prof. Dr., Yıldız Teknik Üniversitesi, Eğitim Fakültesi, İstanbul, Türkiye

ORCID: Ö.G. 0000-0002-8243-3875;

M.G. 0000-0003-1706-9920

Sorumlu yazar/Corresponding author:

Özlem Gürsoy,

Yıldız Teknik Üniversitesi, Atatürk İlkeleri ve İnkılap Tarihi Bölümü, İstanbul, Türkiye

E-posta/E-mail: ogursoyo@hotmail.com

Başvuru/Submitted: 21.04.2021

Revizyon Talebi/Revision Requested: 30.04.2021

Son Revizyon/Last Revision Received:

12.10.2021

Kabul/Accepted: 31.10 .2021

Atıf/Citation: Gursoy, Ozlem. Gunduz, Mustafa. "Cumhuriyet Döneminde Okullarda Askerliğe Hazırlık Kampları Üzerine Bir Sözlü Tarih Çalışması (1935-1947)." Yakın Dönem Türkiye Araştırmaları-Recent Period Turkish Studies 40 (2021): 1-28.

https://doi.org/10.26650/YTA2021-925210
ÖZ

XIX. yüzyıldan itibaren gerek zorunlu askerlik sistemi gerekse topyekûn savaş anlayışı vatandaşların askerlikten önce nitelikli bir askerlik eğitiminden geçirilmesini gerektirince, gençlere okullarda militarist nitelikli derslerle okul dışında da paramiliter örgütler ve izcilik aracılığıyla askerlik eğitimi verilmiştir. I. Dünya Savaşı öncesinde ve sonrasında bu tarz eğitimler II. Meşrutiyet ve Cumhuriyet yıllarında siyasi elitlerin ilgisini çekmiştir. 1926'da Askerliğe Hazırlık Dersleri müfredata konulurken, yaz tatillerinde de öğrenciler Askerliğe Hazırlık Kampları'na götürülerek her an cepheye gidecek şekilde eğitilmiştir. Bu çalışmada, Askerliğe Hazırlık Kampları, öğrenciler cephesinden ele alınmıştır. Bunun için 1935-1947 yılları arasında kamplara katılmış bireylerle sözlü tarih çalışması yapılmıştır. Birinci ağızdan şahitlerle kamplarda neler yaşandığı sunulurken, kampların belgelere yansımayan insani yönleri de gösterilmiştir. Bu çalışma, ilk defa birincil kaynaklarla ve canlı tanıklarla Askerliğe Hazırlık Kampları'nın eğitim tarihindeki yerini göstermeyi amaçlamaktadır.

Anahtar Kelimeler: Militarist Eğitim, Askerliğe Hazırlık Dersleri, Askerliğe Hazırlık Kampları, Sözlü Tarih

\section{ABSTRACT}

Since the 19th century, the compulsory military service system and the concept of total war required citizens to undergo a qualified military training before military service. Thus, young people started to receive training in militaristic classes, paramilitary organizations, and scouting. This type of training appealed to political elites of Second Constitutional and Republic Eras before and after the World War I. As the preparation for military courses was included in the curriculum in 1926, students were taken to the camps on summer holidays and were trained to be war ready. To explore the camps from students' perspective, an oral history study was conducted with individuals who attended camps between 1935 and 1947. While presenting what happened in the camps through witnesses, this study shows the humanitarian aspects of the camps, which are not reflected 
in the documents. In summary this study aims to reveal the place of military service preparation camps in the history of education, using witnesses primary sources.

Keywords: Militarist Education, Preparation for Military Service Courses, Preparation for Military Service Camps, Oral History

\section{Extended Abstract}

Since the 19th century, the change in the understanding of war, the expansion of war zones, and the increasing need for labor force, have made it necessary to channel all resources in a country toward war training. In such an environment, including young people in war required that they will be equipped with military training well before they were enlisted, and so, the contents of civilian schools' curricula were militarized. While military and shooting training courses in schools became a mainstay, military skills were also taught to youth outside of schools, through paramilitary organizations and scouting.

In a short time, these developments in preparing young people for military service in and out of school in Europe were reflected in the Ottoman Empire. As in Europe, especially after the defeat of the Balkan Wars, the contents of the training programs were restructured in order to "raise young people to be war-ready." During the Second Constitutional Era, militarist elements such as medical training, drilling, games, and target practices were added to the contents of the physical training course, and with military course in the curriculum, students were taken to the shooting ranges. In this way, young people were primed for military training in schools. Outside of schools, through the Boy Scout Organization (İzci Ocağı), which was established and directed by the state, and also through paramilitary organizations, such as the Türk Gücü Derneği, the Osmanlı Güç Dernekleri, and the Osmanlı Genç Dernekleri, the same priming was achieved. It should be noted that the idea of creating a "millet-i müsellaha" (nation in arm) under the mobilization conditions of the First World War was also effective in directing political elites to militarist training in this period.

After the proclamation of the Republic, the need to protect the borders of the newly established state amidst the fragile conditions of the 1930s, and the possibility of a new war required constant war preparations. Also, when the effect of shortening the duration of military service is added to this process, it was considered that practical solution for giving basic military knowledge to young people in schools is beneficial. Consequently, the physical education course, which was in the curriculum in the last period of the 
Ottoman Empire, continued to remain in the curriculum unchanged until 1926. However, in 1926, the basic military skill was removed from the content of physical education and added to military education as a separate course. In the academic year of 1926-1927, basic military skill was re-included in the curriculum under the name, preparation for military service. In the first stage, this course was added to the last two years of boys' high schools and boys' schools for teaching, but later, it was taught in all schools from middle school to university with a denser content in the unsafe environment emerged in the mid-1930s. In 1937, when the danger of a new war emerged, female students were also taught the preparation for military service courses.

In addition, after the course was reincluded in the curriculum, the subjects taught under it were shown to the students in the preparation for military service camps during the summer holidays, and in a practical way as well. At the end of school years, students were taken to the camps in August in the first stage. When the number of students required to attend the camps increased due to the widening of the course's scope, high school and university students were taken to camps away from the city during the summer holiday. In these camps, where there were no civilian individuals other than the students, and everything was done in military fashion, getting the students accustomed to military training and service.

In this study, preparation for military service camps will be examined from the point of view of students with the oral history method. For this, interviews were conducted with individuals who participated in these camps between 1935 and 1947. Thus, by discussing the camps with the living witnesses, the humanitarian dimension of the camp life that is not reflected in the documents will be shown. 


\section{Giriș}

Modern devletin itaatkâr, sadık, disiplinli ulus bilincine sahip vatandaşlar yaratmak için kullandığı araçların başında zorunlu askerlik ve zorunlu eğitim sistemi gelmektedir. XVIII. yüzyıldan itibaren herkesi kapsayan ordu ve okul aracılığıyla aynı üniformayı giyen, aynı dili konuşan, aynı marşları söyleyen itaatkâr ve sadık vatandaşlar yaratılmas1 hedeflenmiştir. Böylelikle ordu, ulus-devletlerin vatandaş yaratma projesinin diğer önemli ayağı olan eğitimin şekillenmesinde de etkili olmuştur. ${ }^{1}$ Öyle ki bu hedefe uygun olarak eğitimin içeriği militarist ve milliyetçi öğelerle doldurulmuştur.

Militarizm, etimolojik olarak Latince "askerlik ve savaşa" dair anlamına gelen "militaris"ten türemiş olup Türkçeye “orduculuk" veya "askercilik" olarak çevrilmiştir. Militarizmin anlamında savaş ve savaş hazırlığı ön planda gözükse de Michael Howard militarizmi, "askerî alt kültüre ait değerlerin toplumun egemen değerleri olarak algilaması" şeklinde ifade ederek kültürel özelliğini ileri sürmüştür. ${ }^{3}$ Benzer şekilde tarihçi Alfred Vagts, militarizmi “askerî kurum ve yöntemleri sivil hayatın içinde yükselten her türlü duyguyu, askerî mantaliteyi, karar ve davranış biçimlerini sivil alana taşıyan, her türlü düşünme ve değerlendirme sistemini kapsayan bir olgu "olarak tanımlamıştır." Murat Belge de Vagts gibi sivil militarizmi işaret ederek "toplumun tamamını, çocukluktan başlayarak 'askerî değerler ve normlar' çerçevesinde eğitmek, bu çerçevede davranmaya çağırmak, askerliği askerliğin dışına çıkarmak ve genel bir yaşama üslubu haline getirmek" biçiminde tarif ederken böyle bir yaşam tarzını benimseyen bir toplumun her işi askerî yöntemle yapmaya karar verdiğini ileri sürmüştür. ${ }^{5}$ Bu tanımlardan hareketle militarizm için askerî inanç ve değerlerle sivil hayatı yeniden inşa eden bir zihniyet olduğu söylenebilir. ${ }^{6}$ Bu süreçte okullar da militarist düşüncenin yaygınlaşmasına aracılık etmiştir. Yurttaşlık Bilgisi başta olmak üzere Tarih, Coğrafya, Edebiyat derslerinin içerikleri vatanseverlik, kahramanlık, vatan savunması, cesaret gibi temalarla doldurulurken bir yandan da Beden Eğitimi, Jimnastik ve Askerlik gibi dersler müfredatta yer almaya başlamıştır. XIX. yüzyıl boyunca Avrupa'da okullar, neredeyse milliyetçi ve

1 Ayşe Gül Altınay-Tanıl Bora, “Ordu, Militarizm ve Milliyetçilik”, Modern Türkiye'de Siyasal Düşünce, Milliyetçilik, ed. Tanıl Bora, C.4. İstanbul, İletişim Yayınları, 2002, s. 141-154.

2 Ayşe Gül Altınay, “Militarizm”, Kavram Sözlüğü I: Söylem ve Gerçeklik, der. Fikret Başkaya, Ankara, Özgür Üniversite Kitaplığ1, 2007, s. 351.

3 Michael Howard, War and Nation State, Oxford, Clarendon Press, 1978, s. 109'dan aktaran Ayşe Gül Altınay, "Militarizm", s. 352.

4 Alfred Vagts, History of Militarism: Civilian and Military, New York, The Free Press, 1957, s. 17.

5 Murat Belge, Militarist Modernleşme, İstanbul, İletişim Yayınları, 2012, s. 150.

6 Militarizmin farklı tanımları için bkz. Güven Gürkan Öztan, Türkiye'de Militarizm, Zihniyet, Pratik ve Propaganda, İstanbul, Bilgi Üniversitesi Yayınları, 2014, s. 7-36. 
militarist ideolojiye hizmet eden kurumlara dönüşmüştür. ${ }^{7}$ Bunun yanında okul dışında da gençler, paramiliter gençlik örgütleri ve izcilik organizasyonlarıyla bir yandan askerî talimlerle küçük yaştan itibaren askerliğe alıştırılırken diğer yandan gençlere milliyetçilik, vatanseverlik, disiplin, itaat, vatan için ölme gibi değerler aşılanmıştır. İki savaş arası dönemde başta Almanya ve İtalya olmak üzere Fransa, İngiltere, Rusya, Finlandiya gibi ülkelerde bu amaçlara hizmet eden çok sayıda gençlik örgütü kurulmuştur. ${ }^{8}$

Osmanlı İmparatorluğu'nun son dönemlerinde de beden terbiyesi, izcilik ve paramiliter gençlik örgütleri siyasi elitlerin önem verdiği konulardan biri olmuştur. ${ }^{9}$ Avrupa' da olduğu gibi beden terbiyesi adı altında yapılan etkinliklerle "her an savaşa hazır gençler yetiştirme" isteği, militarist içerikli derslerin müfredata konulmasına neden olmuştur. 1913 'te Tedrisât-1 İptidâiye Kanun-1 Muvakkatı ile ilköğretim müfredatına Terbiye-i Bedeniye ve Mektep Oyunları ile Erkek Çocuklara Askerî Talimler dersleri konulmuştur. ${ }^{10}$ Beden Eğitimi derslerinde "hücum emri", "esir almaca”, "muhafiz", "muhasara topu" gibi savaş ve askerliği yansıtan oyunların oynatılması, öğrencilere nişan tüfeğiyle atış pratiği verilmesi öğrencilerin küçük yaşlardan itibaren askerliğe alıştırılmak istendiğinin bir göstergesidir. ${ }^{11}$ Aynı yıl kurulan Müdâfaa-i Millî Cemiyeti'nin bünyesinde gençleri çevik ve zinde tutmak ve çocuk yaşlardan itibaren askerî yeteneklerini geliştirmek için "Bedeni ve Askeri Mümaresat Heyeti” oluşturulmuştur. Bu heyetin görevleri arasında jimnastik, koşu, yüzücülük, nişancılık, uzun yaya yürüyüşleri, at yarışları, kılıç, kasatura, mızrak kullanma talimleri gibi gençleri bedenî ve askerî antrenmanlara alıştırmak çeşitli sporlar organize etmek ve seyahatler düzenlemek bulunuyordu. ${ }^{12} \mathrm{Bu}$ faaliyetlerin başlamasında Balkan Savaşlarında alınan yenilginin ve I. Dünya Savaşı'nın seferberlik koşullarının itici güç olduğunu söylemek gerekir. ${ }^{13}$

7 Sanem Yamak Ateş, Asker Evlatlar Yetiştirmek, II. Meşrutiyet Dönemi'nde Beden Terbiyesi, Askerî Talim ve Paramiliter Gençlik Örgütleri, İstanbul, İletişim Yayınları, 2012, s. 50-97.

8 Sanem Yamak, "Vatandaşlık Eğitimi ve Militer Eğitim”, Tematik ve Kronolojik Türk Eğitim Tarihi, ed. Mustafa Gündüz, İstanbul, İdeal Kültür Yayıncılık, 2018, s. 307-340.

9 Zafer Toprak, “İttihat ve Terakki’nin Paramiliter Gençlik Örgütleri”, Boğaziçi Üniversitesi Beşerî Bilimler Dergisi, C.VII, 1979, s. 95-113; Erol Akcan, Ittihat ve Terakki Fırkası'nın Paramiliter Gençlik Kuruluşları, Ankara, Türk Tarih Kurumu Yayınları, 2015, s. 215-314; Sadık Sarısaman, "Birinci Dünya Savaşı Sırasında İhtiyat Kuvveti Olarak Kurulan Osmanlı Genç Dernekleri”, OTAM, C.11, S.11 2000, s. 439-501.

10 Mustafa Ergün, II. Meşrutiyet Devrinde Eğitim Hareketleri (1908-1914), Ankara, Ocak Yayınları, 1996, s. 201-202.

11 Mehmet Ö. Alkan, “Osmanlı İmparatorluğu'nda Modernleşme ve Eğitim”, Türkiye Araştırmaları Literatür Dergisi, C.6, S.12, 2008, s. 61; Filiz Meşeci Giorgetti, Eğitim Ritüelleri, İstanbul, Yeni İnsan Yayınevi, 2016, s. 221.

12 Abdülkadir Özcan, "Balkan ve I. Dünya Savaşlarında Hizmeti Geçen Bir Hayır Kurumu”, Doğumunun 100. Yılında Atatürk'e Armağan, İstanbul, İ.Ü.E.F, 1981, s. 275.

13 Mehmet Beşikçi, Birinci Dünya Savaşı'nda Osmanlı Seferberliği, İstanbul, Türkiye İş Bankası Kültür Yayınları, 2015, s. 225-229. 
Gençlerin ulusal savunma amacıyla seferber edilmesi fikri Osmanlı'dan Cumhuriyet dönemine de intikal etmiştir. Dünyanın içinde bulunduğu güvensiz ortamın ve artan savaş tehdidinin dayatması gereğince, Avrupa ülkelerinde olduğu gibi Cumhuriyet’in ilk yıllarında da okullarda ve okul dışında gençlere askerlik eğitimleri verilmiştir. Bunun yanında Cumhuriyet' in ilanından sonra askerlik süresinin kısaltılmas $1^{14}$ askerlikten önce gençlerin askerî eğitimden geçirilmesinde etkili olmuştur. Böylece erken yaşlardan itibaren verilen militer nitelikli eğitimlerle uzun süre askere alınmalar önlenmiştir. Gerek son Osmanlı döneminde gerekse Cumhuriyet'in ilk yıllarında bu tarz askerî eğitimlerin amacı bütün toplumu militarist ruhla bezemekten çok muhtemel bir savaşa hazırlamaktır. Dolayısıyla eğitim sistemi içinde bu eğitimlerin militarist bir eğitimden çok militer bir uygulama olduğunu söylemek mümkündür.

Cumhuriyet'in ilk yıllarında da militarist içerikli beden terbiyesi, jimnastik dersleri ders programlarında kalmaya devam ederken Genelkurmay Başkanlığı'nın girişimleri sonunda Askerlik Dersleri adıyla askerlik ayrı bir ders olarak müfredatta yer almış ve yaz tatillerinde de dersin pratik uygulaması olan Askerliğe Hazırlık Kampları ile öğrencilere askerî eğitimler verilmiştir. ${ }^{15} \mathrm{Bu}$ şekilde bir tutum izlenmesinde siyasi elitlerin bir yandan gürbüz ve yavuz evlatlar ${ }^{16}$ yetiştirme isteği bir yandan da savaş olasılıklarının dayatmasına bağlı olarak yurt savunmasına yönelik izlenen politikalar etkili olmuştur.

Askerliğge Hazırlık Dersi, 22 Eylül 1926'da Bakanlar Kurulu kararı ile 1926-1927 ders yılı başında erkek lise ve erkek öğretmen okullarının son iki sınıfının (3. ve 4. sınıflarında) müfredatına konulmuştur. ${ }^{17} 1927$ 'den itibaren dersin kapsamı genişletilerek yeni eğitim- öğretim y1lından itibaren ortaokullarla birlikte ticaret ve sanat liselerinin çeşitli kademelerinde okutulmaya başlanmıştır. ${ }^{18}$ 1930'ların ortalarından itibaren dünyanın içinde bulunduğu güvensiz ortam ve teyakkuz hali ortaokuldan yüksekokula kadar tüm okul seviyeleriyle birlikte kız öğrencileri de içerecek şekilde dersin kapsamının genişletilmesine neden olmuştur. Bu yıllarda dersin içeriği daha da ağırlaştırılmış; derslerde ve kamplarda hafif ve ağır makineli tüfek kullanılmasının gösterildiği gibi aynı şekilde bu tüfeklerle atışlar yaptırılmış ve mezuniyet için bu dersin teorik ve pratik

14 Salih Akyürek, Zorunlu Askerlik ve Profesyonel Ordu, Rapor No: 24, İstanbul, Bilge Adamlar Stratejik Araştırmalar Merkezi (BILLGESAM), 2010, s. 23.

15 Anılan yıllarda askerî okullarda askerî eğitim doğrultusunda yaz kampı uygulaması mevcuttur. Günümüzde de Millî Savunma Üniversitesi bünyesinde yaz aylarında kamplar düzenlenmektedir.

16 Yiğit Akın, Gürbüz ve Yavuz Evlatlar: Erken Cumhuriyet te Beden Terbiyesi ve Spor, İstanbul, İletişim Yayınları, 2004, s. $87-117$.

17 Maarif Vekâleti Tebliğler Mecmuası, S.10, 10 Teşrin-i Sâni 1926, s. 7-10.

18 Maarif Vekâleti Tebliğler Mecmuası, S.21-24, 15 Kânun-1 Sâni 1927, s. 21. 
bölümlerinden başarılı olma şartı aranmıştır. ${ }^{19}$ II. Dünya Savaşı yıllarında ise Askerliğe Hazırlık Dersleri; Terzilik Okulu'nun, Köy Enstitüleri’nin, Ankara Erkek Lisesi, Galatasaray ve Vefa liseleri gibi “klasik” liselerin ve Gazi Eğitim Enstitüsü'nün Resim ve Müzik bölümlerinin ders programlarında yer almaya başlamıştır. ${ }^{20} 1945$ 'te dersle ilgili birtakım düzenlemeler yapılmış olsa da 11 Ekim 1945'te Cumhurbaşkanı'nın gönderdiği yeni kararnameyle Askerliğe Hazırlık Dersleri Yönetmeliği'nin yürürlükten kaldırıldığı bildirilmiş ve Millî Savunma Öğretimi Yönetmeliği yayımlanmıştır. Bu yeni yönetmeliğin birinci maddesinde dersin amacının "Türk gençliğini yurt savunmasına hazırlamak" olduğunun belirtilmesinden söz konusu dersin geçmiş yillardaki Askerlik Derslerinden farklı bir özellik taşımadığı göze çarpmaktadır. ${ }^{21}$ Bununla birlikte yeni yönetmelikte kız öğrencilere Millî Savunma Kursları düzenlenerek hastabakıcılık, levazım, uçaksavar (uçaksavarcı, 1şıldakçı, radarc1), muhabere (telsizci, santralcı, telefoncu, telgrafçı) vs. gibi ordu hizmetlerine ve yurt için savunma hizmetlerine yönelik eğitimler verilmesi öngörülmüştür. ${ }^{22}$ Görüldüğü üzere II. Dünya Savaşı sona ermesine rağmen "gençlerin her an savaşa hazır olması" fikri güncelliğini korumuş ve Askerlik Derslerinden tamamen vazgeçilememiştir.

Askerlik Dersi'nin eğitim programının bir parçası haline gelmesinde Genelkurmay Başkanlığı'nın büyük rolü olmuştur. Hem derslerin planlanması, hazırlanması ve denetlenmesi hem de ders kitaplarının yazımı ve basımı Genelkurmay Başkanlığı'nın kararıyla gerçekleştirilmiştir. Her okul düzeyine göre farklı içeriklerle yazılan Askerliğe Hazırlık Dersleri kitaplarında genel olarak ordu kurumu, ordu teşkilâtı, askerlik kanunu, askerî terbiye, silahlar ya da silah bilgisi, atış, topografya, seferberlik, muharebe usulü ve harp tarihi konuları ele alınmıştır. II. Dünya Savaşı öncesi ve sırasında ise kitaplarda bunların yanında casusluk, propaganda, istihbarat gibi konulara da yer verilmiştir. Bununla birlikte Coğrafya, Tarih, Malumat-1 Vataniye ve Terbiye-i Bedeniye derslerinin içerikleri de Askerliğe Hazırlık Derslerine uygun bir şekilde düzenlenmiştir. ${ }^{23}$ Böylece, Askerliğe Hazırlık Dersi kitapları öğrencilerin askerlikle ilgili her türlü bilgiyi

19 Askerliğe Hazırlık Dersleri, Askeri Ehliyetnameler ve İhtiyat Subay Hazırlık Kitapları hakkındaki yönetmeliğin yürürlüğe konulması hakkında bkz. Türkiye Cumhuriyeti Cumhurbaşkanlığ $\breve{g}$ Devlet Arşivleri Başkanlı̆̆l Cumhuriyet Arşivi (BCA), Fon Kodu: 30.18.1.2, Yer No: 54.35.20. 09.05.1935.

20 Maarif Vekilliği Tebliğler Dergisi, S.94, 28 Birinciteşrin, 1940, s. 46-53; Maarif Vekilliği Tebliğler Dergisi, S.95, 11 İkinciteşrin, 1940, s. 57; Maarif Vekilliği Tebliğler Dergisi, S.119, 5 May1s 1941, s. 164; Talim ve Terbiye Kurulu Kararı, 21.10.1946, s. 483.

21 Askerliğe Hazırlık Dersleri Yönetmeliği, BCA, Fon Kodu: 30.18.1.2, Yer No: 109.61.9. 11.10.1945; Millî Savunma Öğretimi Yönetmeliği’nin yürürlüğe konulması ve Askerliğe Hazırlık Dersleri Yönetmeliği'nin kaldırılması, BCA, Fon Kodu: 30.18.1.2, Yer No: 113.22.13. 03.03.1947.

22 Milli Savunma Öğretimi Yönetmeliği, Ankara, Genelkurmay Basımevi, 1947, s. 12-13.

23 Maarif Vekâleti Tebliğler Mecmuası, S.10, 10 Teşrin-i Sâni 1926, s. 8-10. 
öğrenmelerine k1lavuzluk etmiştir. Görüldüğü üzere bu dersin öğretmenlerinin okula en yakın garnizonlardaki subaylardan seçilmesi ve sınıfa üniformalarıyla girerek dersi anlatması, dersin rütbeli subayların yazdığı ders kitaplarından takip edilmesi ve yaz tatillerinde öğretilen konuların uygulamalı olarak gösterilmesi öğrencilerin ortaokul yıllarından itibaren temel askerlik bilgileriyle tanışmasına neden olmuştur. ${ }^{24}$

Bu çerçevede çalışmada 1935-1947 yılları arasında Askerliğe Hazırlık Kamplarına katılmış bireylerin kamp deneyimleri sözlü tarih yöntemiyle ele alınacaktır. Sözlü tarih bir disiplinden çok temelinde tarih, sosyoloji, antropoloji, edebiyat gibi alanların olduğu disiplinler arası bir yöntemdir. ${ }^{25}$ Arşiv belgelerinin ve yazılı metinlerin yanı sıra canlı tanıklıklar aracığıyla tarihi yeniden değerlendirmeye, gözden geçirmeye, söylenmeyen veya söylenilemeyenleri ortaya çıkarmaya imkân vermektedir. Paul Thompson'ın işaret ettiği gibi sözlü tarih; resmî tarih anlatılarında yer almayan çocuklar, kadınlar, yaşlılar, işçiler, yoksullar ve marjinalleşmiş gruplar gibi gizli kalmış seslerin, aile ilişkileri, din ve gündelik hayat, suç ve şiddet, gizli kalmış alanların çıkarılmasını sağlayan bir yöntemdir. ${ }^{26}$ Sözlü tarihi diğer araştırma yöntemlerinden ayıran bir diğer özelliği de doğrudan insan kaynağına ulaşılarak resmî tarihe veya arşiv belgelerine yansımayan duyguların görülebilmesini, sağlamasıdır. Bir başka deyişle olaylara hangi duyguların eşlik ettiğini, tarihi olayın belgelere yansımayan insani bir boyutunu göstermektedir. ${ }^{27}$

Bu çalışmada, aşağıdaki tabloda kendileri hakkında bilgi verilen Askerliğe Hazırlık Kamplarına katılmış veya Özden İnönü Toker örneğinde gibi olduğu döneme şahitlik

24 Ders kitapları konusunda yapılmış çalışmalar için bkz. Hande Özdamar, 1930-1945 Arası Dönemde Türkiye'de Militer Anlayış ve Yansıması, İstanbul, İstanbul Bilgi Üniversitesi, Sosyal Bilimler Enstitüsü, Yayımlanmamış Yüksek Lisans Tezi, 2007, s. 55-77; M. Ezel Ünal, Gençler Silah Başına! Ders Kitapları Aracılı̆̆ı̆la Türkiye'de Gençliğin Militarizasyonu (1926-1945), İstanbul, Galatasaray Üniversitesi Sosyal Bilimler Enstitüsü, Yayımlanmamış Yüksek Lisans Tezi, 2014, s. 71-95; Günseli Gümüş̧el, Milli Güvenlik Dersleri Tarihi (1926-2012), Ankara, Berikan Yayınları, 2020, s. 143-320.

25 Paul Thompson, “21. Yüzyılda Sözlü Tarih İçin Potansiyeller ve Meydan Okumalar”, Kuşaklar, Deneyimler, Tanıklıklar İçinde, der. Aynur İlyasoğlu, Gülay Kayacan, İstanbul, Tarih Vakfı Yurt Yayınları, 2006, s. 23.

26 Thompson, "21. Yüzyılda..." s. 27-32.

27 Esra Danacıoğlu, Geçmişin İzleri: Yanıbaşımızdaki Tarih İçin Kılavuz, İstanbul, Tarih Vakfı Yurt Yayınları, 2001, s. 134. 
etmiş kişilerin bireysel belleklerine başvurularak kamp ortamı tasvir edilecektir. ${ }^{28}$ Böylece Askerliğge Hazırlık Kamplarının belgelere yansımayan insani yönü, katılımcıların duygularıyla birlikte gösterilecektir. Ancak kamplara katılan bireylerin deneyimlerinin hepsini burada göstermek mümkün olmadığı için kamp ortamı, eğitimler, etkinlikler, kamp kuralları gibi belli başlı temalar etrafında açıklanacaktır.

\begin{tabular}{|c|c|c|c|c|}
\hline & I Görüşmeciler & Doğum Tarihi & Okul Adı & Meslek \\
\hline 1. & Mehmet Emin ALTAN & 1920 & $\begin{array}{l}\text { Haydarpaşa Lisesi } \\
\text { İstanbul Üniversitesi }\end{array}$ & Akademisyen \\
\hline 2. & Cahit KAYRA & 1917 & $\begin{array}{l}\text { Boğaziçi Lisesi } \\
\text { Ankara Hukuk Fakültesi }\end{array}$ & Enerji Eski Bakanı/ Yazar \\
\hline 3. & Hıfzı TOPUZ & 1925 & $\begin{array}{l}\text { Galatarasay Lisesi } \\
\text { İstanbul Hukuk Fakültesi }\end{array}$ & i Gazeteci/Yazar \\
\hline 4. & Sitk1 ANADOL & 1925 & $\begin{array}{l}\text { İstanbul Erkek Lisesi } \\
\text { Teknik Üniversite }\end{array}$ & İnşaat Mühendisi \\
\hline 5. & $\begin{array}{l}\text { Ziya } \\
\text { MÜEZZINOĞLU }\end{array}$ & 1921 & $\begin{array}{l}\text { Kayseri Lisesi } \\
\text { Mülkiye Mektebi }\end{array}$ & $\begin{array}{l}\text { Maliyeci/Maliye Eski } \\
\text { Bakanı }\end{array}$ \\
\hline 6. & Doğan HAŞHAŞ & 1927 & $\begin{array}{l}\text { Erzurum Lisesi } \\
\text { İstanbul Üniversitesi Fen } \\
\text { Fakültesi }\end{array}$ & Fizik Öğretmeni \\
\hline 7. & Turgut BULUT & 1926 & $\begin{array}{l}\text { Bursa Erkek Lisesi } \\
\text { Ankara Hukuk Fakültesi }\end{array}$ & Avukat \\
\hline 8. & $\begin{array}{l}\text { Muharrem } \\
\text { ÖZMELEK }\end{array}$ & 1925 & $\begin{array}{l}\text { Balıkesir Lisesi } \\
\text { Teknik Üniversite }\end{array}$ & Mimar \\
\hline 9. & Orhan YAVUZ & 1924 & $\begin{array}{l}\text { Afyon Lisesi } \\
\text { Teknik Üniversitesi }\end{array}$ & İnşaat Mühendisi/ Sanayici \\
\hline 10. & $\begin{array}{l}\text { Ali Hüsrev } \\
\text { BOZER }\end{array}$ & 1923 & $\begin{array}{l}\text { Maarif Koleji } \\
\text { Ankara Hukuk Fakültesi }\end{array}$ & Akademisyen/ Siyasetçi \\
\hline 11. & $\begin{array}{l}\text { Özden İNÖNÜ } \\
\text { TOKER }\end{array}$ & 1930 & $\begin{array}{l}\text { Ankara Kız Lisesi } \\
\text { Dil ve Tarih Coğrafya } \\
\text { Fakültesi }\end{array}$ & İnönü Vakfı Başkanı \\
\hline 12. & Özcan KÖKNEL & 1928 & $\begin{array}{l}\text { Kabataş Erkek Lisesi } \\
\text { İstanbul Tıp Fakültesi }\end{array}$ & Akademisyen/Doktor \\
\hline 13. & Sazi SïREL & 1925 & $\begin{array}{l}\text { Galatarasay Lisesi } \\
\text { Güzel Sanatlar Fakültesi }\end{array}$ & Akademisyen \\
\hline
\end{tabular}

28 Görüşmecilere, erişilebilen şahıslar veya onların önerdiği kişiler vasıtasıyla ulaşılmıştır. Telefonda yapılan ön görüşmeyle çalışma hakkında bilgi verildikten sonra kabulleri doğrultusunda kendilerinin belirledikleri yer ve saatte görüşmeler gerçekleştirilmiştir. Söyleşiye başlamadan önce araştırmanın amacı tekrar açıklanarak konuşmaların ses kayıt cihazına kaydedilmesi için kendilerinden izin alınmıştır. Görüşmenin ardından kayıtların deşifresi yapılmıştır. Bunların görüşme ile aynı gün içinde yapılmasına özen gösterilmiştir. Deşifre yapılırken görüşmecilerin ifadeleri üzerinde herhangi bir değişiklik yapılmamıştır. Bütün görüşmecilerin ses ve görüntüleri, anlatıları ve kişisel bilgileri bilgisayar ortamında ayrı ayrı dosyalar halinde muhafaza edilmiştir. Daha sonra burada verilen bilgiler, birincil kaynaklarla ve diğer görüşmecilerin anlatılarıyla karşılaştırılarak bilgilerin doğruluk ve güvenirliliği sağlanmıştır. Toplanan verilerin ayrıntılı analizlerinin yapılması ve yorumlanması için sorulan sorular çerçevesinden birtakım temalar oluşturularak bir kodlama listesi yapılmıştır. Kodlamanın ardından kod açma işlemine geçilerek daha önceden belirlenen temalar çerçevesinde kodlanan anlatılar ayrı dosyalarda toplanmıştır. Örneğin "Askerliğe Hazırlık Kamplarına katıldınız mı?" konusuyla ilgili bütün anlatılar aynı dosyada bir araya getirilmiştir. Belirlenen temalardan konu başlıkları oluşturularak görüşmecilerin anlatıları yorumlanmıştır. 


\begin{tabular}{|l|l|l|l|l|}
\hline 14. & $\begin{array}{l}\text { Ruhi } \\
\text { KAFESCIOĞLU }\end{array}$ & 1920 & $\begin{array}{l}\text { Sivas Lisesi } \\
\text { Teknik Üniversite }\end{array}$ & Akademisyen \\
\hline 15. & $\begin{array}{l}\text { Ali İhsan } \\
\text { FUTACI }\end{array}$ & 1923 & $\begin{array}{l}\text { Bursa Lisesi } \\
\text { İstanbul Tıp Fakültesi }\end{array}$ & Uzman Doktor \\
\hline 16. & Galip UZUNCA & 1923 & $\begin{array}{l}\text { Haydarpaşa Lisesi } \\
\text { İstanbul Tip Fakültesi }\end{array}$ & Uzman Doktor/ Şair \\
\hline 17. & $\begin{array}{l}\text { Rober } \\
\text { HADDECIYAN }\end{array}$ & 1926 & $\begin{array}{l}\text { Mihitaryan Ermeni } \\
\text { Okulu İstanbul Edebiyat } \\
\text { Fakültesi }\end{array}$ & Gazeteci/Yazar \\
\hline 18. & $\begin{array}{l}\text { Aram } \\
\text { KAMBURYAN }\end{array}$ & 1926 & $\begin{array}{l}\text { Mihitaryan Ermeni Okulu } \\
\text { Teknik Üniversite }\end{array}$ & İnşaat Mühendisi \\
\hline 19. & $\begin{array}{l}\text { Tophane Sanat Enstitüsü } \\
\text { Teknik Yüksek Öğretmen } \\
\text { KARABACAK }\end{array}$ & 1929 & Elektrik Öğretmeni \\
\hline
\end{tabular}

Tablo 1: Görüşmeciler Hakkında Bilgiler

Tabloda belirtilen kişilerin 20'si ile yüz yüze görüşme yapılabilmiştir. Özcan Köknel, sarı nokta hastalığı sebebiyle telefonda görüşme yapmayı tercih etmiştir. Orhan Yavuz ise yüz yüze görüşmeyi kabul etmemesine rağmen soruları e-posta ile cevaplayıp göndermiştir. Ancak bir görüşmecinin verdiği bilgilerin doğruluğundan emin olamadığını söylemesi ve bunların çalışmaya konulmamasını rica etmesi nedeniyle onun anlatıları çalışmaya dâhil edilmemiştir. Bir diğer görüşmecinin ise kamp anılarını yedek subaylıkla karıştırdığ fark edilince, verdiği bilgilerin tutarlı olmadığ görülmüş ve anlatıları çalışmaya konulmamıştır. Askerliğe Hazırlık Kamplarına sadece erkek öğrencilerin katılması zorunlu olduğu için görüşmeciler erkek bireylerden seçilmiştir. Bunun yanında İsmet İnönü'nün kızı Özden İnönü Toker'den Ömer ve Erdal İnönü’nün kamp anıları ile kamp uygulamalarına ilişkin birtakım bilgilere ulaşılmıştır.

Görüşmecilerin hem yaşları hem de anılarının üzerinden uzun yıllar geçmiş olması itibarıyla anıların unutulması, öğrencilik yıllarındaki askerlik kampı anıları ile yedek subaylık anılarının karıştırılması ve çarpıtılması ihtimaline karşı anlatılar arşiv belgeleriyle, mevcut literatürle ve diğer görüşmecilerin anlatılarıyla karşılaştırılarak bilgilerin doğruluğu, güvenilirliği ve geçerliliği sağlanmıştır. Bununla birlikte anlatılarda görüşmecilerin söylemleri değiştirilmeden, orijinal hali ile verilmiştir.

\section{Anılarda Askerliğe Hazırlık Kampları}

Askerliğe Hazırlık Kamplarına katılmış bireylerin anılarına geçmeden konunun daha iyi anlaşılması için kamplarla ilgili genel bilgi vermek faydalı olacaktır. Kamplar, lise ve üniversite eğitimi sırasında erkek öğrencilere yaz tatillerinde devreler halinde düzenlenmiştir. Talimatnamelerde belirtildiğine göre kampların amacı "gençleri yurt 
savunmasına hazırlamak"tır. ${ }^{29}$ Talim ve Terbiye Dairesi'nin kurul kararlarında ise kamplarla gençlerde askerlik sevgisinin oluşturulmak istendiği belirtilmiştir. ${ }^{30}$ Bunun yanında burada askerliğe hazırlanan gençlerin herhangi bir savaş durumunda ülkenin korunması durumunda büyüklerinin önünde sinav vererek dünya tarihinde yeni kahramanlıklara imza atabileceğine kanaat getirilmiştir. Bir yandan da kampların sonunda gençlerde güçlü bir sağlık ve neşe belirerek sağlam vücutlarıyla, sağlam dimağ ve enerjilerini yurt savunmasında kullanmaya hazır hale gelecekleri düşünülmüştür. ${ }^{31}$ Dolayısıyla Askerliğe Hazırlık Kampları ile hem gençlerin askerlik sevgisinin ve ruhunun geliştirilmesi hem de açık havada yapılan egzersiz ve uzun yürüyüşlerle bedenlerinin güçlendirilmesi amaçlanmıştır. Bu doğrultuda 1926'da dersin müfredata konulmasıyla birlikte öğretim yılının sonunda erkek liseleri ve öğretmen okullarının son sınıf öğrencileri 1-15 Ağustos tarihleri arasında kamplara götürülmüştür. ${ }^{32} 1935$ 'te Askerliğe Hazırlık Dersi'nin kapsamının genişletilmesine bağlı olarak resmî ve özel liseler, tüccar, kaptan ve çarkçı okulları ile üniversite, yüksekokullar ve muadillerinin çeşitli kademelerindeki öğrencilerin kamplara katılması zorunlu olmuştur. ${ }^{33}$ Ayrıca üniversite öğrencilerinin kamplarının talim taburlarında gerçekleştirilmesine ${ }^{34}$ ve kamp süresinin 1 . ve 2 . sınıflar için 15'er günden toplam 30 gün olmasına karar verilmiştir. ${ }^{35}$ II. Dünya Savaş1 başladıktan sonra 1940'ta yayınlanan bir kararnameyle kamp süresi 20 güne çıkarılmıştır. ${ }^{36}$ Dolayısıyla hem dersin kapsamının genişletilmesi ve içeriğinin ağırlaştırılmasıyla hem de kamp sürelerinin artırılmasıyla okulların kışla görünümü kazandığını söylemek mümkündür.

Yukarıda da değinildiği gibi sağlığı yerinde olan tüm erkek öğrencilerin kamplara katılması zorunluydu. Sağlık durumu elverişsiz, bedenen zayıf ve hasta olan ve bunu okul doktorundan aldıkları raporla belgeleyen öğrencilerin kamplardan muaf tutulacağı ve mazeretsiz olarak kampa katılmayan öğrencilerin davranış notlarının yarıya düşürüleceği öğrencilere bildirilmişti. ${ }^{37}$ Öğrencilerin mazeretlerinin geçmesi veya sağlıklarına

29 Askerliğe Hazırlık Dersleri (1935), s. 1; Askerliğe Hazırlık Dersleri Yönetmeliği (1940), s. 1.

30 "Madde-19", Askerliğe Hazırlık Dersleri Yönetmeliği (1945), s. 10.

31 Türkiye Cumhuriyeti Maarifi 1940-1941, İstanbul, Maarif Matbaası, 1941, s. 114.

32 Maarif Vekâleti Tebliğler Mecmuası, S.10, Teşrin-i Sâni 1926, s. 7; "Madde 14", Askerliğe Hazırlık Tedrisatı: Askeri Ehliyetnameler ve İhtiyat Zabiti Hazırlık Kıt'aları Hakkında Talimatname D-60, Ankara, Türkiye Cumhuriyeti Erkân-1 Harbiye Umûmiye Riyaseti, 1927, s. 8.

33 Askerliğe Hazırlık Dersleri: Askeri Ehliyetnameler ve İhtiyat Subay Hazırlık Kıt'aları Hakkında Talimatname D-60, Ankara, Genelkurmay Matbaası, 1935, s. 6.

34 "Madde-27”, Askerliğe Hazırlık Dersleri (1935), s. 11-12.

35 "Madde-19", Askerliğe Hazırlık Dersleri (1935), s. 10.

36 Askerliğe Hazırlı Dersleri Hakkında Talimatname D-60, Ankara, Genelkurmay Matbaası, 1940, s. 6.

37 Maarif Vekâleti Tebliğler Mecmuası, S.25-26, 15 Mart 1928, s. 60. 
kavuşmaları halinde hangi okul seviyesinde olursa olsun eksik kalan kampları tamamlaması gerekiyordu. ${ }^{38}$ Ayrıca derslerde ve kamplarda başarılı olan öğrencilere "askerî ehliyetname" veriliyordu. Öğrencilerin her öğrenim düzeyine göre hazırlanmış bu ehliyetnameleri alması için ders programlarında mevcut olan Askerlik Dersi'ni görmeleri, kamplardaki askerî talim ve tatbikatlara katılmaları, silahla atış yapmaları ve kamp sonunda da ehliyetname imtihanlarını başarıyla vermiş olmaları gerekiyordu. ${ }^{39}$ Ancak 1938-1939 ders yılından itibaren askerî ehliyetname uygulamasına son verilmiş ve bir üst sınıfa geçmek için öğrencilerin kamp bitimindeki sınavlardan başarılı olmaları esas alınmışt1. $^{40}$

Görüldüğü üzere 1935'ten itibaren dersin kapsamının genişletilmesi ve 1940'a gelince kamp sürelerinin artırılması, derslerin ve kampların amacının “ülke gençliğini yurt savunması için savaşa hazırlamak"41 olduğunun belirtilmesi, gençlerin topyekûn bir savunmaya hazırlandıklarının bir göstergesidir. Öte yandan bir öğrencinin yüksekokuldan mezun oluncaya kadar lisenin ilk sınıfindan itibaren 5 kez kamplara katılmasının zorunlu olduğu ${ }^{42}$ düşünülürse Askerliğe Hazırlık Kampları ile öğrencilerin askerlikten önce temel askerlik bilgi ve pratiği konusunda epeyce bir deneyim kazandıkları söylenebilir.

Bu çalışmada Askerliğe Hazırlık Kamplarına katılmış bireylerin belleklerine başvurularak öğrencilerin kamp deneyimleri gösterilecektir. ${ }^{43}$ Ancak bu deneyimlerin hepsini burada göstermek mümkün olmadığı için kamp ortamı, eğitimler, etkinlikler, kamp kuralları gibi belli başı temalar etrafında açıklanacaktır.

\subsubsection{Kamp Hayatı}

İlk aşamada süresi 15 gün olan Askerliğe Hazırlık Kampları, II. Dünya Savaşı yıllarında 20 güne çıkarılmıştır. Diğer açık hava etkinliklerinde olduğu gibi kampların şehir merkezinden uzak, kır hayatının her türlü ihtiyaçlarını sağlayan yerlerde kurulmasına dikkat edilmiştir. ${ }^{44}$ Aşağıdaki tabloda da görüleceği üzere kamp yeri olarak İstanbul' daki Kilyos, Sarıyer gibi sayfiye yerler ile o yıllarda boş arazilerin yoğun olduğu Kağıthane

38 "Madde-5", Askerliğe Hazırlık Tedrisatı (1935), s. 7; Maarif Vekilliği Tebliğler Dergisi, S.31, 12.07.1939, s. 143.

39 "Madde-38", Askerliğe Hazırlık Tedrisatı (1927), s. 13.

40 Maarif Vekilliği Tebliğler Dergisi, S.31, 12.07.1939, s. 143.

41 Askerliğe Hazırlık Dersleri Hakkında Talimatname (1940), s. 1.

42 Türkiye Cumhuriyeti Maarifi 1940-1941, s. 116.

43 Lise öğrencilerinin kamp deneyimlerini gazeteler, öğrenci dergileri ve anılar üzerinden ele alan bir başka çalışma için bkz. Sevda Kazankaya, Asker Liseliler: Musiki Muallim Mektebi Özelinde Askerlik Dersleri ve Uygulamasl, Ankara, Hacettepe Üniversitesi, Sosyal Bilimler Enstitüsü, Yayımlanmamış Yüksek Lisans Tezi, 2020, s. 66-73.

44 “Madde-12", Askerliğe Hazırlık Tedrisatı (1927), s. 10; "Madde-11”, Askerliğe Hazırlık Dersleri (1940), s. 7. 
ve Ayazağa tercih edilmiştir. Ankara'daki kamp yerleri için Özden İnönü’nün hatırladığ1 kadarıyla kampların Çubuk Barajı tarafinda kurulduğu, daha çok Kayaş civarına gidildiği, ağabeyleri Erdal ve Ömer İnönü’nün değişik yerlerde kurulan kamplara katıldığ1 anlatılmıştır. ${ }^{45}$

Anlatılardan yola çıkılarak görüşmecilerin lise ve üniversite yıllarında gittikleri kamp yerleri şöyle gösterilebilir:

\begin{tabular}{|c|c|c|}
\hline \multirow{2}{*}{ Kamplara Katılanlar } & \multicolumn{2}{|c|}{ Kamp Yeri ve Tarihi } \\
\hline & Lise & Üniversite \\
\hline Mehmet Emin ALTAN & Okul Bahçesi (?) & $\begin{array}{c}\text { Süleymaniye civarı } \\
\text { (1938-1942 y1llar1 arası) }\end{array}$ \\
\hline Cahit KAYRA & Kağıthane (?) & Sarıkışla (1936)46 \\
\hline Hifzı TOPUZ & $\begin{array}{c}\text { Kilyos } \\
\text { (1939 ve 1940) }\end{array}$ & Hatırlanmadı \\
\hline Sitkı ANADOL & Okul Bahçesi (?) & $\begin{array}{c}\text { Ayazağa-Büyükçekmece } \\
\text { 1942-1945 arası }\end{array}$ \\
\hline Doğan HAŞHAŞ & Belirtilmedi & $\begin{array}{l}\text { Mavramoloz Ormanları } 47 \\
\text { (1949 veya } 1950)\end{array}$ \\
\hline Turgut BULUT & Belirtilmedi & Sarıkışla (1945 ve 1946) \\
\hline Muharrem ÖZMELEK & $\begin{array}{l}\text { Namazgah (Balıkesir) } \\
\quad(1941 \text { ve 1942) }\end{array}$ & Ayazağa (1943) \\
\hline Orhan YAVUZ & Okul Bahçesi (?) & Maslak (?) \\
\hline Ali Hüsrev BOZER & Belirtilmedi & $\begin{array}{c}\text { Çankaya istikametinde bir dağın üstü } \\
(?)\end{array}$ \\
\hline Özcan KÖKNEL & Okul Bahçesi (?) & $\begin{array}{c}\text { Ayazağa ve Rumeli Feneri } \\
(1945)\end{array}$ \\
\hline Şazi SİREL & $\begin{array}{c}\text { Galatasaray Lisesi } \\
\text { Sarıyer'e yakın bir yer } \\
\text { (1942 veya 1943) }\end{array}$ & Hatırlanmadı \\
\hline Ruhi KAFESCİOĞLU & $\begin{array}{l}\text { Çermik (Sivas)48 } \\
\text { (1935 veya 1936) }\end{array}$ & $\begin{array}{l}\text { Selimiye Kışlası } \\
\text { (1938 ve1939) }\end{array}$ \\
\hline Ali İhsan FUTACI & $\begin{array}{l}\text { Temenyeri (Bursa)49 } \\
\text { (1940) }\end{array}$ & Ayazağa (1943) \\
\hline Galip UZUNCA & $\begin{array}{l}\text { Okul Bahçesi } \\
\text { (1940) }\end{array}$ & Ayazağa (?) \\
\hline Rober HADDECIYAN & Hatırlanmadı & Ayazağa -Bakırköy (?) \\
\hline Aram KAMBURYAN & $\begin{array}{l}\text { Hürriyet Tepesi } \\
(1941,1942)\end{array}$ & Ayazağa (1945 ve 1946) \\
\hline
\end{tabular}

Tablo 2: Askerliğe Hazırlık Kampı Yerleri

45 Özden İnönü Toker ile 17 Kasım 2018'de yapılan görüşme.

46 Sarıkışla, Ankara'nın şehir merkezine yaklaşık olarak yarım saat uzaklıkta yer alan en önemli askerî yapılardan birisidir.

47 Sarıer'in sırtlarındaki doğal orman alanı.

48 Sivas'ın Yıldız Eli ilçesinin sınırları içinde yer almaktadır.

49 Bursa'nın Yıldırım ilçesinin sınırları içinde kalan semt ve park alanı. 
Tablodan görüldüğü üzere görüşmeciler lise ve üniversite kamplarını ayrı yerlere yapmıştır. Lise kamplarının 1940’a kadar okul dışında gerçekleştirildiği, II. Dünya Savaşı yıllarında ise kamp için okul bahçesinin kullanıldı̆̆ı görülmektedir. Lise yıllarında kamplara katılan görüşmeciler atış talimleri için okul çevresinde bulunan boş arazilere götürüldüklerini belirtmişlerdir. Hıfzı Topuz, Ayazağa’nın o yıllardaki durumu anlatırken burada geçen eğlenceli sayılabilecek bir anısını da şöyle aktarmıştır:

“ilk askerlik kampına Ayazağa'ya gittim. 1939-40 yıllarında. Ayazağa biliyorsunuz Mecidiyeköy'den sonra tek bina yoktu, bomboş araziydi. Çok eğlenceli geçiyordu kamplar. Hatta şöyle bir anım var kampta: Orası Ayază̆a. Bir çeşme vardı, pınar vardı daha doğrusu. Böyle kalabalık bir yer değildi. Köylüleri çok az görüyorduk ve o pınara diyorlardı ki: ‘Geceleri buraya bir peri, peri kızı gelir. Orası perili pınar!’ diye anılırdı. Biz inanmıyorduk tabii. Bir gece silahlarımızı aldık, gittik, nöbet tuttuk. Ben iki arkadaşımla beraber peri gelecek diye bekledim. " 50

Görüşmeciler, lise yıllarında dışarıdan satın aldıkları üniformalarıyla okula gelerek silahları teslim aldıktan sonra toplu bir şekilde okulun yakınında bulunan boş arazilere götürüldüklerini ve burada atış talimleri yaptıklarını anlatmıştır. Anlatılardan lise kamplarında öğrencilere temel düzeyde askerlik eğitimi verildiği görülmektedir. Lise eğitimini Bursa Lisesi'nde alan Ali İhsan Futacı, lisedeki kamp deneyimini şöyle ifade etmiştir:

“Lise kamplarına lise 1'de gittim. 20 gün sürüyordu. 1 Teтmuz 20 Temmuz arasinda. Kamplar Temenyeri'de olurdu. Evde yatıp kalkardık, sabahleyin okula giderdik. Silahlarımız falan okuldaydı. Önce okula gidiyorduk. Teçhizatımız, silahlar falan okuldaydı. Oradan silahlarımızı alıyorduk, taburlarla çıkar Temenyeri'ye giderdik. Şimdi teleferiğin olduğu yer var ya, Piremir diyorlar oraları kırdl, orada atışa giderdik. Mavzer denilen tüfekler vardı. Şimdikiler gibi değildi. Orada atış yapardık, hakiki mermi ile. Kimin ne kadar atış yaptı̆̆ kaydedilirdi. Lisede çadırda kalmadık. Evde kalırdık, okula giderdik. Okuldan silahlanıp talime çıkardık. Silahları bırakı, tekrar eve dönerdik. Yorgunluktan, yemeği yer yemez küt diye yatardık. Öyle böyle halimiz kalmazdı. Çok talim yaptırırlardl, yat-kalk.",51

Özcan Köknel de Kabataş Erkek Lisesi’ne başladığında 9. sınıfta kampa gittiğini söylemiştir. Okulda kendilerine verilen tüfekleri omuzlarına alıp, Ortaköy'ün tepelerine yürüdüklerini, burada kendilerine dörtte bir asker somununun verildiğini ve talimlerden sonra okula dönülüp silahların bırakıldığını, herkesin evlerine dağıldığını ve bunların 20 gün sürdüğünü ifade etmiştir. Okullara üniformayla gelinmesi, tüfeklerin verilmesi ve en yakın garnizondan gelen subay öğretmen tarafından atış talimleri yaptırılması bu yıllarda okullar adeta bir kışlayı andırdığını göstermektedir.

50 Hifzı Topuz ile 26 Temmuz 2018' de yapılan görüşme.

51 Ali İhsan Futacı ile 20 Nisan 2019'da yapılan görüşme. 
Bununla birlikte İstanbul'daki üniversite kampları ile talim taburlarının genel olarak Ayazağa' da gerçekleştirildiği anlaşılmaktadır. Ayazağa'nın kamp yeri olarak seçilmesinde görüşmecilerin deyişiyle "bomboş bir arazi” den ibaret olması ve atış yapmaya uygunluğu geçerli olan nedendir. Üniversite kamplarının ise gerek kamp ortamı gerekse verilen eğitimler bakımından tam bir askerî havada gerçekleştiği anlaşılmaktadır. Anlatılara göre bireysel veya toplu bir şekilde kamp yerine ulaşan öğrenciler ilk önce saç kontrolünden geçirilmiş ve saçı ve sakalı uzun olanların kamp berberine gönderilerek saçlar 2, 3 veya 0 numaraya vurulmuştur. Bundan sonra öğrencilere kamp süresi boyunca eğitimlerde ve talimlerde giymeleri zorunlu olan asker elbiseleri verilmiştir. Kendi bedenlerine uygun olarak verilen kıyafetlerin kampın sonunda teslim edildiği belirtilmiştir. Kıyafetlerini almalarının ardından kamptaki öğrencilerin sayısına göre askerî birliklere ayrılarak kendilerinden sorumlu subaylarla tanışmışlardır. Tanışma faslı bitince öğrencilere kalacakları çadırlar gösterilmiştir. Bir çadırda en az 6 en fazla 12 kişinin bulunduğunu ifade eden görüşmeciler, çadırların kurulumu konusunu farklı şekillerde anımsamıştır. Bazıları koni şeklindeki bu çadırların daha önceden kurulduğunu ve bunları hazır bulduklarını söylerken bazıları da çadırları kampa gelince kendilerinin kurduğunu anlatmışlardır. Bu konudaki en kesin ifade Aram Kamburyan tarafından verilmiştir. Kamburyan, çadırları kendilerinin kurduğunu, çadırın çökmesinden dolayı bunu hiç unutamadığını dile getirmiştir. ${ }^{52}$ Bununla birlikte talimatnamelerde belirtildiği üzere yüksekokulların kamp yerlerinin talim tabur ve alay komutanlarıyla üniversite rektörleri ve garnizon komutanlığınca birlikte seçileceğinin bildirilmesi $^{53}$ üzerine kamplar için kışlaların da tercih edildiği Cahit Kayra ve Turgut Bulut'un anlatılarından anlaşılmaktadır. Cahit Kayra ve Turgut Bulut, kamplar için Sarıkışla'ya götürüldüklerini, burada kışlanın ikinci katının kendilerine tahsis edildiğini ve bu nedenle ranzada uyuduklarını söylemiştir. ${ }^{54}$ Buradan hareketle bütün üniversite kamplarının açık havada ve çadır konaklamalı gerçekleşmediği söylenebilir.

Ali Hüsrev Bozer üniversite yıllarındaki kamp ortamını şöyle tasvir etmiştir:

“Hukuk Fakültesi'nde iken 1. ve 2. sinıfta kamp vard. Bu kamplar 20'şer gündü. Ankara'nın uzakça bir yerinde bir dă̆ın tepesinde askerlik görevini yerine getirirdik. Şartlar son derece kötü idi. Çadırlarda kalıyorduk. Bir zihniyet var, çok doğru: 'Askerlik meşakkat işidir.' Onun için çadırlarda 10'ar kişi yatardık. Yatakların içinde makaralar, şunlar bunlar vardı. Batar her tarafinıza. Tuvalet diye bir yer yok. 500 ya da 700 metre giderdiniz, kuyular açılmıştı. O kuyulara def-i tabiyede bulunurdunuz. Hatta bir gün ben beyaz eşofman giyerdim. Gece karanlikta nöbetçi asker bana silahını dayadı. Korktum. Hafta sonu çıkılmazdı kamptan. " 55

52 Aram Kamburyan ile 7 Kasım 2019'da yapılan görüşme.

53 Askerliğe Hazırlık Dersleri Yönetmeliği (1945), s. 9.

54 Cahit Kayra ile 19 Temmuz 2018'de ve Turgut Bulut ile 15 Eylül 2018'de yapılan görüşmeler.

55 Ali Hüsrev Bozer ile 14 Kasım 2018'de yapılan görüşme. 
Kamptaki görevlilere gelince talimatnamelerde 1927'de kampların idaresinden okul müdürü, muavini ve askerlik öğretmeninin sorumlu tutulacağ1, 1935'te ise bu görevlilerin yanına garnizondan ayrıca subay atanacağı bildirilmiştir. 1945'te bu konuyla ilgili yeni bir düzenleme yapılarak kamplar için gerekli olan yardımcı subaylar, bu kampların idaresine yetecek kadar erbaş, erler ve araçların kolordu garnizon komutanlıklarınca sağlanacağı belirtilmiştir. ${ }^{56}$ Anlatılarda ise kampların işleyişinden albay rütbesindeki bir kamp komutanının sorumlu olduğu kamplardaki eğitimlerin ve talimlerin teğmen, yüzbaşı, binbaşı rütbesindeki subaylar tarafından verildiği, onlara yardımcı olmak üzere çavuşlar ve erlerin görevlendirildiği bilgisi aktarılmıştır. Genel olarak görüşmecilerin kamptaki komutanların rütbelerini hatırladıkları görülmüştür. Hatta Galip Uzunca, Haydarpaşa Lisesi'nin kamp komutanının Alparslan Türkeş olduğunu söylemiştir. ${ }^{57}$

Bunun yanında kamp komutanları içinde "Rommel"s8 lakaplı bir subay dikkat çekmiştir. Birçok anlatıda kamp komutanlarının Rommel gibi sert olmasından dolayı kendisine bu benzetmenin yapıldı̆̆ı söylenmiştir. Örneğin Ali İhsan Futacı, "Kamp komutanını hatırlıyor musunuz?" sorusunu "Bir Rommel'i hatırlıyorum. Biz Rommel derdik" diye cevaplamıştır. Galip Uzunca, kendi kamplarında Rommel'in bulunduğunu kendisinden sonraki devrede de Rommel'in devam ettiğini belirtmiştir. Aram Kamburyan ise kampta "Bizim Rommel" adını verdikleri bir askerlik hocası olduğunu anlatmıştır. “Rommel” hakkında Özden İnönü de Ömer İnönü’nün Pendik’teki üniversite kampında başlarındaki komutana kendilerinin "Rommel” adını taktıklarını anlattığından bahsetmiştir. Mehmet Emin Altan ise üniversite kampında Almanya'da eğitim görmüş komutan binbaşılardan biri için "Rommel'in arkadaşı" diye söylendiğini anlatmıştır. ${ }^{59}$ Öte yandan "Rommel" adına bazı hatıratlarda da rastlanmıştır. Örneğin; 1943-1950 yıllarında Darüşşafaka Lisesi'nde öğrenci olan Sami Musluoğlu, Pendik’teki kampta görev yapan askerlik hocası için "Rommel derdik, hani Afrika'da Alman Rommel vardı ya, ondan da sert bir adamdı." şeklinde bir söylemde bulunmuştur. Şu haliyle "Rommel" lakaplı askerlik dersini veren binbaşının veya kamp komutanının efsaneleştiği ve görüşmecileri etkilediği görülebilmektedir.

Kamplardaki görevliler arasında bir kamp doktoru da bulunuyordu. Görüşmeciler, çadırlardan birinin sıhhiye çadırı olarak kullanıldığını ve doktorların her gün kampları ziyaret ettiklerini belirtmişlerdir. Ruhi Kafescioğlu, bu sıhhiye çadırında ufak tefek

56 "Madde-8", Askerliğe Hazırlık Tedrisatı (1927), s. 8; "Madde-14", Askerliğe Hazırlık Dersleri (1935), s. 9; "Madde22”, Askerliğe Hazırlı Dersleri Yönetmeliği (1945), s. 11.

57 Galip Uzunca ile 30 Ağustos 2019'da yapılan görüşme.

58 Johannes Erwin Eugen Rommel, II. Dünya Savaşı'nda Alman Afrika Kolordusu Komutanı.

59 Mehmet Emin Altan ile 11 Temmuz 2018'de yapılan görüşme. 
sıyrıklara pansuman yapıldığını, Özcan Köknel ise aynı askerlikte olduğu gibi şikâyeti olanların sabah 07.00 veya 08.00'da revire çıktığını; şikâyete göre ya istirahat verildiğini ya da tedavi edildiğini anlatmıştır. ${ }^{60}$ Anlatılarda bu görevliler dışında sivil hiçbir kimsenin bulunmadığının altı çizilmiştir.

Görüşmecilere, komutanların kendilerine yaklaşımı sorulduğunda genel olarak "asker gibi" davranıldığını, ciddi olduklarını ancak kaba bir şekilde davranmadıklarını söylenmişlerdir. Hatta kamp komutanlarını sevecen, kendilerini ürkütmeyen, babacan ve iyi şeklinde değerlendirilenler de olmuştur. Örneğin, Mehmet Emin Altan, komutanların kendilerine yaklaşımının gayet iyi olduğunu, kendilerine "Ulan!" diye bir hitapta bulunmadıklarını söylemiştir. Aynı şekilde Muharrem Özmelek de komutanların sert olmadıklarını belirterek, bu durumu genç olmalarıyla ilişkilendirmiş ve "Gençlerdi. Biz 18, onlar 20 yaşında." diye ifade etmiştir. Ruhi Kafescioğlu ise lise kampındaki komutanla yaşanan bir durum karşısında kendilerine rahatlıkla "Biz mi cezalıyız, içerideki mi cezalı?" diye sorabildiklerini, genelde çok sevecen, çok kucaklayıcı olduklarını anımsarken, kamp komutanlarından itici ve sert bir davranış görmediğini, kendilerine karşı hoşgörülü davrandıklarını söylemiştir. ${ }^{61}$ Buna karşın Turgut Bulut, komutanların kendilerine karşı yaklaşımlarının birbirinden farklı olduğunu, komutana göre değiştiğini söyleyerek kendi başındakini "haşin bir adam" olarak değerlendirmiştir. Cahit Kayra ise lise kampındaki binbaşının çok sert olduğunu ve ondan çok şikâyet ettiklerini, üniversite kampının yapıldığı Sarıkışla'da sadece çavuşu gördüklerini ve onun da çok kötü ve çocukları ciddiye almadığını söylemiştir. Benzer şekilde Galip Uzunca da komutanlarının kendilerini önemsemediklerini anlatmıştır. Görüldüğü üzere komutanların öğrencilere yaklaŞımı kamptan kampa farklılık göstermiştir.

Kamplardaki yemekler konusunda görüşmeciler tarafından yemeklerin askerlikte olduğu gibi karavana usulünde yendiği ifade edilmiştir. Bu konuda Muharrem Özmelek, yemeklerin erler tarafından masalarda kendilerine servis edildiğini, ekmekten suya varıncaya kadar her şeyin onlar tarafından verildiğini, kendilerinden hizmet beklenilmediğini ve üstelik komutanların da kendileriyle birlikte aynı masada yemek yediklerini, Mehmet Emin Altan da askerî usulde onar kişilik yahut sekizer kişilik masalarda karavanın geldiğini ve herkesin kabına öyle dağıtılıp, öyle yenildiğini, Orhan Yavuz ise yemeklerin açık alanda ranza ve masada yenildiğini anlatmıştır. ${ }^{62}$ Ali İhsan Futacı, yemekleri nasıl yediklerini şu sözlerle anlatmıştır:

60 Ruhi Kafescioğlu ile 10 Ocak 2019'da ve Özcan Köknel ile 1 Aralık 2018'de yapılan görüşmeler.

61 Mehmet Emin Altan ile 11 Temmuz 2018'de ve Muharrem Özmelek ile 24 Eylül 2018'de yapılan görüşmeler.

62 Orhan Yavuz ile 10 Ekim 2018'de yapılan görüşme. 
"Yemekler karavana ile gelirdi. Böyle büyük bir şey. İçinde 12 parça et vardı. Herkes onu tabağına kordu, ondan yerdik. 12 kişilik verirlerdi. Bir arkadaş vardı. Böyle karavana dağıtılırdi. Her mangadan bir kişi gider, o manganın yemeğini alırdı."

Çoğunlukla yemeklerin bol ve lezzetli olduğu anımsansa da Ali Hüsrev Bozer yemeklerin kötü olduğunu, Turgut Bulut ise yemeklerin içinde sineklerin gezdiğini söylemiştir. Hatta bu durumu komutanlarına bildirdiklerinde kendilerine "Asker! sinek yenmeyecek!" denildiğini aktarmıştır.

Görüldüğü üzere anlatılardan gerek lise kampları gerek verilen eğitimler gerekse düzen bakımından ciddi bir askerlik kampı hayatının yaşatılmadığı söylenebilir. Hatta görüşmeciler içinde bu kampları "ciddi bir şey değildi” diye değerlendirenler olmuştur. Buna karşın anlatılardan üniversite kamplarının gerek organizasyonu gerekse söz konusu ortamı itibariyle kışladan farksız olduğu anlaşılmaktadır. Bu kışla hayatı hissi, öğrencilere kurallarla ve verilen eğitimler ve görevlerle iyice hissettirilmiştir.

\subsubsection{Kamplardaki Eğitimler ve Nöbet}

Askerliğe Hazırlık Kamplarındaki uygulamalar arasında askerî muharebe şekilleri, çeşitli pozisyonlarda ve muhtelif mesafelerden çeşitli hedeflere atışlar, 25-30 kilometrelik yaya yürüyüşler, molalar, ordugâhların kurulması, karakol, devriye, nöbet hizmetleri, gözcü, keşif kolu vazifeleri, hayvan tımarı ve bakımı bulunuyordu. ${ }^{63}$ Görüşmeciler, anlatılarda okudukları bölüme göre kendilerine piyade veya topçu eğitimi verildiğini, eğitimlerde dönüşler, yatış-kalkış, silah doldurup boşaltma yaptırıldığını ve silah bakımı gibi konuların öğretildiğini ifade etmiştir. Görüşmeciler genel olarak eğitimlerin kahvaltıdan sonra saat 07.00-08.00 sularında başladığını anımsamıştır. Özcan Köknel, kamplarda yapılan faaliyetleri şöyle ifade etmiştir:

“Ayazağa'daki kampta sabah 7'de başlardl. Kahvaltı ederdik, sonra 8'de silahlarla yürüyüşe çıkardık. Üstelik orada atış falan da yapardık. Silahla karşıda hedef vardı. O hedefleri vurma şeklinde falan. Yani tamamen bir askeri bölükte ne talim yapllyyorsa erlere o talimlere aynen katılırdık bizde. Sabah 8'de başlayıp 11.30'a kadar, öğleden sonra da 2'de başlayıp 5'e kadar, 6’ya kadar sürüyordu. Bunların içinde yürüyüş vard, yerde sürünme vardl, yat-kalk vardı. Bu tür şeyler vardl."

Orhan Yavuz ise kampta kapalı bir eğitim alanı olmadığını, muharebeye hazırlık eğitimlerinin teğmen rütbesindeki subaylar gözetiminde deneyimli çavuşlar tarafından verildiğini, atış poligonunu olup olmadığını hatırlamadığını; ancak bazuka ile bir atış

63 Türkiye Cumhuriyeti Maarifi 1923-1943, s. 113-114. 
yaptığını söylemiştir. Bunların dışında eğitimlerde silahların tanıtılması, bakımı ile muharebeye hazırlık için fizik geliştirme çalışmalarının yapıldığını belirtmiştir.

Yine kamptaki eğitimler kapsamında çok sıkı olmasa da gece yürüyüşlerinin yapıld1ğ1 anlatılmıştır. Mehmet Emin Altan, yürüyüşlerde Fenerbahçe’ye kadar gittiklerini, komutanların köprüden geçerken uygun adım geçmenin zararlı olduğunu, "uygun adım olursa rezonans olarak köprüye yansır. Köprünün salınımı artarak köprü yıkılır.” dediklerinden dolayı uygun adımla köprüden geçmediklerini aktarmıştır. Galip Uzunca, lise kamplarında kendilerinin geceleri Çamlıca'ya götürüldüğünü, burada farklı okullarla rakip haline getirilerek bir esir alma mizanseni yapıldığını söylemiştir.

Atış eğitimleri hakkında kamp yerinin dışında bir tepe, kır gibi yerlere götürülerek oralarda atışlar yaptırıldığı belirtilmiştir. Yönetmeliklere göre atışların bir cetvele kaydedilmesi gerekiyordu. Görüşmecilere atışların kaydedilip kaydedilmediği sorulduğunda bu konunun farklı anımsandığı görülmüştür. Bazıları böyle bir şeyi hatırlamadığını bazıları da böyle bir uygulamanın olmadığını söylemiştir. Atışların defterlere kaydedildiğini anımsayanlar da atıştan iyi not alamayanların Askerlik Dersi’nden kaldığını belirtmişlerdir.

Kamplardaki faaliyetler içinde nöbet görevi de bulunuyordu. Nöbetin askerlikteki en kutsal görevlerden biri olduğunu, bir askerin nöbet esnasındaki görev ve sorumluluklarını derslerde kavrayan öğrenciler, kamplarda da bu görevi deneyimleme imkânı yakalamıştır. Nöbet görevi konusu da atış çizelgesinde olduğu gibi farklı şekilde hatırlanmıştır. Bazıları nöbet görevinin olmadığını veya hatırlamadığını söylerken bazıları da geceleri iki saat nöbet tuttuklarını belirtmiştir. Örneğin; Ali İhsan Futacı, nöbet için "Yoktu. Olsa hatırlardım.” diye söylerken, Özcan Köknel, gece nöbetlerinin akşam 20.00' da başladığını, ikişer saat arayla tutulduğunu, nöbeti biten kim varsa arkadaşını uyandırarak, ona havale ettiğini anlatmıştır. Sıtkı Anadol, nöbet deneyimini şöyle anlatmıştır:

"Nöbet tutuyorduk. Gece nöbeti vardl. Herkes iki saat tutardı. Ben biraz o zaman da aykırı bir çocuktum. Gece 1-3 arası senin nöbetin var değil mi? Senden önceki nöbeti olan geliyor, "benim nöbetim bitti, kalk nöbete" derdi. Beni uyandırdıkları zaman, 'kalk Sitkl, nöbete gideceksin!' dediği zaman yanına bir arkadaşı alıyordu. 'kalk nöbete' deyince vuruyordum başımı yatıyordum. Tabii ben yatınca benden sonraki tamamiyla bozuluyordu. Sabahleyin subay gelince herkes 'beni kaldırmadılar' deyince suçlu bulunamıyordu. Baştakilerden bir iki tanesi suçlanıyordu. Ondan dolayı beni kaldırırlarken: 'bak Sitkı! Seni kaldırdık, nöbet sıran geldi. Bu da şahittir.' diye iki kişi gelirdi beni kaldırmaya. Bunlar aklımda kalmış. " ${ }^{64}$

64 Sitk1 Anadol ile 14 Ağustos 2018'de yapılan görüşme. 
Genel olarak anlatılardan nöbet görevinin görüşmecilere zor gelmediği anlaşılmaktadır. Görüldüğü üzere bir askerliğin ilk aşamasında erlere hangi eğitimler veriliyorsa kamplarda da aynı eğitimler verilmiş ve nöbet tutturulmuştur. Bunun yanında, görüşmecilerin bütün çalışmaların askerî disiplin içinde yapıldığı konusunda hemfikir olduğu göze çarpmıştır. Görüşmeciler, kamp kuralları hakkında bilgi vererek kampın disiplininin nasıl sağlandığını anlatmıştır.

\subsubsection{Kampın Kuralları ve Disiplini}

Açık hava etkinliklerinin belli bir düzen içinde geçmesi için yatma, kalkma, yemek ve banyo zamanları gibi değişmeyen kendine özgü kuralları bulunmaktadır. ${ }^{65}$ Anlatılarda görüşmeciler, Askerliğe Hazırlık Kamplarındaki hangi faaliyetin ne zaman yapıldığı ve yatış-kalkış saatleri konusunda ortalama bir bilgi verebilmiştir. Örneğin Özcan Köknel, eğitimlerin sabah 08.00'da başlayıp 11.30'a kadar, öğleden sonra da 14.00'da başlayıp 17.00-18.00'a kadar sürdügünü; Ali İhsan Futacı, sabah 07.00-08.00'da toplanıldı̆ğını ve talime çıkarıldıklarını, öğle yemeği yenilmesinin ardından 1-2 saat istirahat edilip, 18.00'a kadar yine bir talim yaptıklarını; Galip Uzunca da akşam 17.00'a kadar talim, 17.00'dan sonra bir eğlence saati olduğunu ve saat 21.00-22.00 gibi çadırlara gittiklerini; Muharrem Özmelek ise 08.00'da jimnastik hareketleri olduğunu, talimlerin 10.00'a doğru başlayıp akşam sularında bittiğini dile getirmiştir.

Bütün anlatılarda kampların çok disiplinli olduğu vurgulanmıştır. Hatta görüşmeciler, disiplinli olduklarından dolayı herhangi bir ceza almadıklarını ifade etmişlerdir. Öte yandan bazı görüşmeciler kamp kurallarına uymayanlar olduğunu onlara yaptırım olarak çadır hapsi cezası veya ceza nöbeti verildiğini belirtmiştir. Örneğin Ruhi Kafescioğlu, kusur işleyenlerin kusurlarına göre ceza verildiğini, bunlar arasında hapis cezası çadırda kalma, dışarı çıkma yasağı, kapısında nöbet tutturma olduğunu anlatmıştır. Galip Uzunca da kamp kuralarına uymayanlara çadır hapsi verildiğini, karar ne kadarsa o kadar çadırda kaldıklarını, önünde de iki tane nöbetçi bulunduğunu ve kesinlikle çadırdan dışarı çıkılamadığını belirtmiştir. Hıfzı Topuz, kamp kurallarına uymayanların nöbet sayısının artırıldığını ve gece nöbetine kalkmak güç olduğundan gece nöbeti verildiğini söylemiştir. Bununla birlikte kamp kurallarını ihlâl edenlere nöbet dışında farklı cezaların verildiği de anlatılmıştır. Örneğin Ali Hüsrev Bozer, kamptan kaçtığı için ceza aldığını şöyle anlatmıştır:

"Her hafta kaçıyorduk. Bir seferinde küçük minibüsler vardl. Gayet ilkel. Ankara'nın kazası ile Ankara arasında işlerdi. O arabaya tesadüfen doktorun kız kardeşi de binmişti. Bizi ihbar etti. Hakikaten bizi yakaladılar. Ertesi gün benim saçlar gitti."

65 Ístanbul Talebe ve Öğretmen Kampları, İstanbul, Ülkü Basımevi, 1939, s. 51. 
Sonuç olarak kamp kurallarını ihlâl edenlere talimatnamelerde belirtildiği gibi uyarı, azarlama, kamp notunun kırılması, kamptan çıkarılma gibi cezalar verilmemesine karŞın çadır hapsi, fazladan nöbet, dışarı çıkma yasağı gibi cezaların uygulandığı anlaşılmaktadır. Bunlar talimatnamedeki cezalara göre daha hafif gibi görülse de o yaştaki gençler için aslında ağır anlamlar taşımaktadır. Bir başka deyişle, verilen bu cezalar öğrencilerde arkadaşlarından dışlanma, topluluktan uzaklaştırılma, izole edilme veya Ali Hüsrev Bozer'in örneğinde olduğu gibi küçük düşürülme gibi duyguların yaşanmasına neden olduğu gibi o yaştaki öğrenciler üzerinde güçlü tesirler bırakması da muhtemeldir. Öyle ki Ali Hüsrev Bozer, neredeyse 70 y1l önce kendisine verilen bu saç kesme cezasını unutamamıştır.

\subsubsection{Kampların Değerlendirilmesi}

Askerliğe Hazırlık Kampları ile ilgili olan görüşmeciler içinde kampların bireysel yaşamlarına katkıları yanında yedek subay eğitimine faydalarını da dile getirenler olmuştur. Mehmet Emin Altan, kamp hayatının fiziksel ve ruhsal açıdan faydalı olduğunu söylemiştir. Cahit Kayra, kampları 15 gün boyunca "evden kurtulma” şeklinde değerlendirerek buradaki havayı evden farkl1, kendi deyimiyle "değişik bir şey" olarak tanımlayarak kamptan memnun kaldığını belirtmiştir. Benzer şekilde Turgut Bulut da kampı bir "kaçış" gibi düşünmüş ve bunu "güzeldi, kaçmak iyiydi." diye ifade etmiştir. Hıfzı Topuz ise kampların farklı bir yönüne işaret ederek zengin-fakir bütün öğrencilerin bu kamplara katılmasıyla öğrenciler arasında bir çeşit "eşitlik" sağladığını ve kendisinin kamp hayatına alışı olmasından dolayı herhangi bir yabancılık çekmediğini şu söyleriyle dile getirmiştir:

"Bir defa bazı arkadaşlar varlıklı arkadaşlardı. Kamp hayatı falan görmemişlerdi. Galatasaray'da hele genellikle varlıklı arkadaşlar vardı. Hayatlarında yeni bir dönem. Başka bir şeyler ögrendiler. Güçlüklere alıştılar. Benim için öyle olmadı. Gayet doğal geliyordu. Galatasaray'daki kamptan önce de Kartal'da çiftliğimiz vardı. Ağabeyimle kamp kurardı. Çadıra çıkardık orada. Ben hiç yadırgamadım bunları. Bahçede bir yerde çadır kurulu orada kalırdik. Gayet eğlenceli geçerdi."

Hıfzı Topuz’un bu sözlerinden kamplara her kesimden gelen öğrencilerle askerlikteki "bir olma" duygusunun askerlikten önce yaşatıldığı söylenebilir. Bu da zaten kampların genel amaçları içinde yer alıyordu. Yine Hıfzı Topuz, kampların arkadaş ve çevre gelişimine katkıda bulunduğunu, birçok insanla arkadaş, dost olduğunu ve bunların yıllarca devam ettiğini belirtmiştir. Sıtkı Anadolu ise aynı çadırda kalmanın ve bir arada yemek yemenin dayanışmayı geliştirdiğini, aynı şekilde Orhan Yavuz da uzun 
yürüyüşlerin ve talimlerin arkadaşlık ve yardımlaşma ilişkilerini geliştirdiğini ve güçlendirdiğini söylemiştir.

Doğan Haşhaş, Orhan Yavuz ve Ali Hüsrev Bozer'in Askerliğe Hazırlık Kampları ile ilgili değerlendirmelerinde, kampların disiplin kazandırma işlevi dikkat çekmiştir. Doğan Haşhaş, kampların sadece disiplinli olmayı öğretmediğini; kendi yatağını yapma, kendi sağlığına bakma, karnını iyi doyurma gibi kazanımları da olduğunu söylemiştir. ${ }^{66}$

Özcan Köknel, kampların birçok açıdan faydalı olduğunu ileri sürmüştür. Burada askerlik eğitimi yanında arkadaşlarını yakından tanıma, farklı kentlerden gelen insanlarla tanışma firsatı bulduğunu söyleyerek kamp hayatının katkısını şöyle ifade etmiştir:

"Bir kere askeri daha yakından tanımak imkânı bulduk. İkincisi yurdun değişik yörelerinden, değişik kentlerinden gelen insanları tanıma imkânı verdi. Onların yaşantısını da yakından görme imkânı vardı. Askerde ve kamplarda birçok şeyi görerek, yaşayarak öğrendiğimiz için bunlar daha kalıcı oldu. Disipline uymayı ögrendik. İlkelere kurallara uymayı öğrendik. İlkelerin, kuralların dışına çıktı̆̆ımız zaman bir kişiye zarar verebileceğimizi yaşayarak öğrendik. Bunların karşıllğında bir cezanın olabileceğini yahut birçok şeyin yitirilebileceğini gene yaşayarak öğrendik."

Galip Uzunca ise burada aldıkları eğitimlerin yedek subaylıkta işine yaradığına dikkat çekerek kamplara katıldığı için iki ay önce terhis olduğunu belirtmiştir. Benzer şekilde Şazi Sirel de burada gördüğü piyade eğitiminin askerlikte işine yaradığını, her şeyi bildiği için arkadaşlarına yardım ettiğini anlatmıştır. ${ }^{67}$

Öte yandan görüşmeciler içinde Askerliğe Hazırlık Kamplarını faydalı bulmayan, gereksiz görenler de mevcuttur. Ali İhsan Futacı bunları "boşa masraf” olarak değerlendirmiş ve bunu "hiç yapılmasa iyiydi, faydalı bir şey olmadı" şeklinde açıklamıştır. Benzer şekilde Muharrem Özmelek de kampların anlamsız olduğuna inanarak bunu şu sözleriyle ifade etmiştir:

"Hiçbir katkısı olmadı. Yalnız bizim askeri mektepte olup da bize gelenler vardı. "Çekilecek kahır değil." derlerdi. Gelen 1,2 arkadaşımız. Biz bu kampların lüzumlu olduğuna inanmadık. Kerhen gittik oraya. Çünkü biz bir anlam veremiyorduk kamplara. Bu kadar zaman içinde asker olsan ne olur, asker olmasan ne olur? Nitekim yanlışlık belli oldu. Bugün askerlik tamamen profesyoneller. Çünkü piyade tüfeği denilen tüfeği veriyorsunuz askere, karşıldaki düşman seni 100 metreden seni gözünden vuruyor. O silahla doğmuş. Zaten eğitimi bu. Sen hedef olarak çıkıyorsun. Dönsen de dönemesen de o sana yapıştırıyor. Yani ciddiye almadık."

66 Doğan Haşhaş ile 7 Eylül 2018'de yapılan görüşme.

67 Şazi Sirel ile 8 Aralık 2018'de yapılan görüşme. 
Her ne kadar Muharrem Özmelek ve Ali İhsan Futacı Askerliğe Hazırlık Kampları'nı faydasız, gereksiz, göstermelik bir uygulama gibi düşünse de görüşmecilerin birçoğunun kamplar hakkındaki kanaatlerinde olumsuz bir durum hissedilmemiştir.

Askerliğe Hazırlık Kampları'nın esas amacı, gençleri yurt savunmasına hazırlamak idi. Ancak görüşmecilerin söylemlerinde burada "bir asker gibi yetiştirildiklerine" dair doğrudan bir vurgu göze çarpmamış; ancak burada her an askere alınacak gibi yetiştirildiklerine inanmışlardır. Anlatılarda kampları daha çok arkadaşıı, disiplin, itaat, yokluğu dayanma bakımından faydalı bulunması dikkat çekmektedir. Esasen bunlar kampların genel amaçları içinde yer alıyordu. Dolayısıyla kamplara katılan bireylerin bunları özümsediği görülmektedir. Buradan hareketle kampların doğrudan "yurt savunmasına hazırlama" misyonundan çok dolaylı olarak askerî değerleri benimsetme özelliğinin öğrencilerde karşıllık bulduğu söylenebilir.

\section{Sonuç}

İki savaş arası dönemde savaşların karmaşıklaşması, mekanikleşmesi, daha fazla insan gücüne ihtiyaç duyulması ve askerlik sürelerinin kısalması askerlerin olduğu kadar sıradan insanların da askerlik eğitiminden geçirilmesini zorunlu kılmıştır. Böyle bir ortamda Cumhuriyet' in ilk yıllarında gençleri orduya alınmadan askerliğe alıştırmak, temel askerlik bilgileri edinmelerini sağlamak için askerî kamp uygulamaları başlamıştır.

Askerliğe Hazırlık Derslerinde öğretilen teknik bilgilerin pratiğinin yapıldığ 1 bu kamplarda, bir savaş olasılığg karşısında gençlerin bedenen ve ruhen savaşa hazırlanmas1 sağlanmış, öğrenciler lise çağlarından itibaren kışla hayatıyla tanıştırılmıştır. Bu çalışmada görüşülen bireylerin kamplara katıldıkları yıllar II. Dünya Savaşı yıllarına denk gelmiştir. Görüşmecilerin anlatılarından savaş yılları olmasından dolayı burada her an asker gibi eğitildiklerine inandıkları gözlenmiştir. Ancak kamplara katılan bireylerin bu kamplarda sadece askerliğe hazırlanmadıkları; aynı zamanda kampların onlara kısa süreli aileden, okuldan, yaşadığ 1 yerden uzaklaşma, toplu bir şekilde yaşama, birlikte hareket etme, mahrumiyete katlanma gibi farklı deneyimler kazandırdığı da anlaşılmaktadır. Dolayısıyla kamplarla gençlerin bir yandan yurt savunmasına hazırlanması diğer yandan da sosyal yönden gelişimleri sağlanmıştır.

Askerliğge Hazırlık Kamplarının görüşmeciler tarafından farklı açılardan anlamlandırıldığ1 tespit edilmiştir. Şöyle ki kampların "disiplinli olma” işlevinin olduğunu düşünenler eğitim için bunu gerekli görmüştür. Bazıları da gerek derslerde ve kamp süresince komutanların askerliğin meşakkatli olduğuna dair telkinlerinin gerekse kampların 
savaş yıllarında gerçekleşmesinin etkisiyle kampları bir eğitim "rutini” olarak değerlendirmiştir.

Bununla birlikte görüşmecilerin söylemlerinde askerliğin, askerlik mesleğinin ve kampların yüceltildiği görülmemektedir. Onlar için kamplara katılım "kutsal bir görev" olarak sayılmamıştır. Daha çok burada ev ve okul yaşantısı dişında farklı bir hava ile karşılaşılmasından kaynaklanan bir "memnun olma” hali göze çarpmıştır. Kampların kışla ortamını andıran ortamı, uygulamaları ve askerî disiplini, 6-10 kişiyle aynı çadırda kalmak, toprağa serili içi saman veya eğrelti otlarıyla dolu yataklarda uyumak, olumsuz tuvalet ve banyo koşulları gibi durumlar karşısında görüşmecilerin rahatsız olmadıkları görülmüştür. Bu durum gerek Askerliğe Hazırlık Derslerinde gerekse başta Tarih ve Yurt Bilgisi dersleri olmak üzere diğer ders kitaplarında da askerlik ruhunun ve sevgisinin sürekli canlı tutulmasıyla ilişkilendirilebilir. Bir başka deyişle, derslerde ve kitaplarda askerî terbiye içinde geçen disiplin, itaat, arkadaş sevgisi, yoklukla mücadele gibi askerî değerlere yapılan vurguların, selamlama ve nöbet gibi askerî ritüelleri Cumhuriyet'in bu ilk kuşağının bir bölümü tarafından içselleştirilmiştir. Bu yönüyle Askerliğe Hazırlık Kamplarının Cumhuriyet' in "disiplinli ve itaatli" nesil yetiştirme amacına hizmet ettiği söylenebilir.

Askerliğe Hazırlık Kampları, Osmanlı'nın son döneminde başlayan “millet-i müsellaha" oluşturma fikrinin bir uzantısı, Alman askerî düşüncesinin etkisi olarak değerlendirilmelidir. II. Meşrutiyet yıllarında toplumun savaşa seferber edilmesine aracı olan paramiliter örgütlenmelerle gençlere kazandırılmak istenen askerî ruh, askerlik bilgi ve becerileri Cumhuriyet'in ilk yıllarında Askerliğe Hazırlık Kampları yoluyla gerçekleştirilmiştir. Bir başka ifadeyle II. Meşrutiyet yıllarında gençlik derneklerinin gençleri “yurt savunmasına hazırlama" işi, Cumhuriyet' in ilk yıllarında bizzat devlet tarafından okullar aracılığıyla yapılmıştır.

Sözlü tarih çalışmasıyla görüşmecilerin anlatılarının arşiv belgeleriyle ve yazılı metinlerde yer alan bilgilerle örtüştüğü görülmüştür. Bunun yanında yazılı kaynaklarda nadiren yer bulan deneyimlerin paylaşılması, kaybolmaya mahkûm bilgilerin kayıt altına alınmasını sağlamıştır. Ayrıca canlı tanıkların tecrübelerine yer verilmesi araştırmaya insanî bir boyut katmıştır. Askerliğe Hazırlık Kampları deneyimlerine hangi duyguların eşlik ettiğini görmemizi sağlamıştır. Kampa katılan bireyler, burada kendilerinin karşılaştıkları veya şahit oldukları durumları anlatırken bir yandan da mutluluk, şaşkınlık, heyecan, üzüntü gibi duygularını aktarmışlardır. Örneğin Askerliğe Hazırlık Kamplarına katıldığı halde çok az şey hatırladığını söyleyen Rober Haddeciyan, Ayazağa' daki kamp 
sırasında hiç unutamadığı bir olayı üzerinden çok uzun zaman geçmesine rağmen mutlu bir ifadeyle anlatmıştır. ${ }^{6}$ Aram Kamburyan, üniversite kampından dönerken artan ekmekleri toplayan arkadaşından düşük bir ses tonu ve üzüntülü bir ifadeyle dile getirmiştir. Doğan Haşhaş, serbest zamanlarda biriyle güreşirken onu sirt üstü düşürdügünü anlatırken yüzünde bir gurur belirmiştir. Hıfzı Topuz, Kilyos kampında uzaktan görülen bir uçağın Alman savaş uçağı zannedilmesi üzerine korkuya kapılıp, heyecanla ellerine silahları alıp beklediklerini söylemiştir.

Görüşmecilerin birçoğu Askerliğe Hazırlık Kampları hakkında ilk defa konuştuklarını söylemiştir. Hıfzı Topuz, bunu "Hiç kampları anlatacağımı düşünmemiştim. Yine de aklıma birçok şey geldi kamplara dair. Hiç kimse sormamıştı.” şeklinde ifade etmiştir. Ali İhsan Futacı, kamp fotoğraflarını paylaşırken "Sevindim, ilk defa böyle bir şeye kullanılacak, tarihe geçmiş olacak. Yoksa benim arşivimde kalacaktı.” sözleri çalışmanın amacını özetlemektedir. Ayrıca Cumhuriyet'in ilk kuşağı olarak görülebilecek sıradan bir doktor, avukat, öğretmen, mimar, mühendis ile tanınmış akademisyen, siyasetçi, yazar bu çalışmayla eğitim tarihi içinde ilk defa bir araya getirilmiştir. Böylelikle eğitim tarihi içinde nesne konumundan çıkarılan bireyler burada tarihin öznesi konumunda bulunmuşlardır.

Askerliğe Hazırlık Kampları ile ilgili bu zamana kadar yapılan çalışmalar gazete, dergi ve anı kitaplarındaki kısa anlatıların aktarılmasından ibarettir. Bu çalışmada ilk kez 1935-1947 yılları arasında Askerliğe Hazırlık Kamplarına katılan bireylerin deneyimleri gözler önüne serilmiştir. Dolayısıyla yakın tarihinin derinliklerinde kalmış bir konunun dönemin şahitleri sayesinde daha anlaşılır ve açık hale gelmesi sağlanmıştır.

1947'den sonra Askerliğe Hazırlık Dersi'nin müfredattaki ağırlığı azaltılsa da varlıklarını uzun süre devam ettirmiştir. Bu süreçte erkek öğrencilerin askerlik kampları sürerken kız öğrencilere yönelik yaz tatillerinde hastabakıcılık ve ilk yardım eğitimlerinin verildiği kurslar düzenlenmiştir. Dolayısıyla eğitimin sisteminin militer ruhunun dönemlere göre nasıl devam ettiği, sosyo-kültürel ve siyasi etkiler karşısında nasıl değişimlere uğradığı ayrıca incelenecek konular arasındadır. Bu araştırmanın, Cumhuriyet'in ilk dönemlerine odaklanmasının, sonrasında yapılacak çalışmalar için bir zemin oluşturduğuna inanılmaktadır.

68 Rober Haddeciyan ile 10 Eylül 2019'da yapılan görüşme. 
Hakem Değerlendirmesi: Dış bağımsız.

Çıkar Çatışması: Yazarlar çıkar çatışması bildirmemiştir.

Finansal Destek: Yazarlar bu çalışma için finansal destek almadığını beyan etmiştir.

Peer-review: Externally peer-reviewed.

Conflict of Interest: The authors have no conflict of interest to declare.

Grant Support: The authors declared that this study has received no financial support.

\section{KAYNAKÇA}

\section{Arşiv Belgeleri ${ }^{69}$}

Türkiye Cumhuriyeti Cumhurbaşkanlı̆̆ Devlet Arşivleri Başkanlığı Cumhuriyet Arşivi (BCA) Talim ve Terbiye Dairesi, Kararlar, 1929-1947

\section{Süreli Yayınlar ${ }^{70}$}

\section{Maarif Vekâleti Tebliğler Mecmuası}

Maarif Vekâleti Tebliğler Dergisi

\section{Araştırma Eserler}

Akcan, Erol: İttihat ve Terakki Fırkası'nın Paramiliter Gençlik Kuruluşları, Ankara, Türk Tarih Kurumu Yayınları, 2015.

Akın, Yiğit: Gürbüz ve Yavuz Evlatlar: Erken Cumhuriyet'te Beden Terbiyesi ve Spor, İstanbul, İletişim Yayınları, 2004.

Akyürek, Salih: Zorunlu Askerlik ve Profesyonel Ordu, Rapor No: 24, İstanbul, Bilge Adamlar Stratejik Araştırmalar Merkezi (BİLGESAM), 2010.

Alkan, Mehmet Ö.: "Osmanlı İmparatorluğu'nda Modernleşme ve Eğitim”, Türkiye Araştırmaları Literatür Dergisi, C.6, S.12, 2008, s. 9-84.

Altınay, Ayşe Gül-Bora, Tanıl: "Ordu, Militarizm ve Milliyetçilik", Modern Türkiye'de Siyasal Düşünce, Milliyetçilik, der. Tanıl Bora, C.4, İstanbul, İletişim Yayınları, 2002, s. $140-154$.

Altınay, Ayşe Gül: "Militarizm”, Kavram Sözlüğ̈̈ I: Söylem ve Gerçek, der. Fikret Başkaya, Ankara, Özgür Üniversite Kitaplığı, 2007, s. 351-366. 
Yamak Ateş, Sanem: Asker Evlatlar Yetiştirmek, II. Meşrutiyet Dönemi'nde Beden Terbiyesi, Askerî Talim ve Paramiliter Gençlik Örgütleri, İstanbul, İletişim Yayınları, 2012.

Belge, Murat: Militarist Modernleşme, İstanbul, İletişim Yayınları, 2012.

Beşikçi, Mehmet: Birinci Dünya Savaşı ’nda Osmanlı Seferberliği, İstanbul, Türkiye İş Bankası Kültür Yayınları, 2015.

Danacıŏ̆lu, Esra: Geçmişin İzleri: Yanıbaşımızdaki Tarih İçin Kılavuz, İstanbul, Tarih Vakfi Yurt Yayınları, 2001.

Ergün, Mustafa: II. Meşrutiyet Devrinde Eğitim Hareketleri (1908-1914), Ankara, Ocak Yayınlar1, 1996.

Meşeci Giorgetti, Filiz: Eğitim Ritüelleri, İstanbul, Yeni İnsan Yayınevi, 2016.

Gündüz, Mustafa: “Türk Eğitim Sisteminde Aşırı Militarist Uygulamanın Başlaması (1926-1947)", Erdem Insan ve Toplum Bilimleri Dergisi, S.71-72, Aralık 2016Haziran 2017, s. 69-88.

Günseli, Gümüşel: Milli Güvenlik Dersleri (1926-2012), Ankara, Berikan Yayınlar1, 2020.

Kazankaya, Sevda: Asker Liseliler: Musiki Muallim Mektebi Özelinde Askerlik Dersleri ve Uygulaması, Ankara, Hacettepe Üniversitesi, Sosyal Bilimler Enstitüsü, Yayımlanmamış Yüksek Lisans Tezi, 2020.

Özcan, Abdülkadir: "Balkan ve I. Dünya Savaşlarında Hizmeti Geçen Bir Hayır Kurumu”, Doğumunun 100. Yllında Atatürk'e Armağan, İstanbul, İ.Ü.E.F, 1981, s. 270-295.

Özdamar, Hande: 1930-1945 Arası Dönemde Türkiye’de Militer Anlayış ve Yansıması, İstanbul, İstanbul Bilgi Üniversitesi, Sosyal Bilimler Enstitüsü, Yayımlanmamış Yüksek Lisans Tezi, 2007.

Öztan, Güven Gürkan: Türkiye’de Militarizm, Zihniyet, Pratik ve Propaganda, İstanbul, İstanbul Bilgi Üniversitesi Yayınları, 2014.

Paksuniemi, Merja: "Mobilising Children for National Defence: Boys Education in the Finnish Civil Guard Organisation During the Second World War", Childhood in the Past, 2016, s. 44-57.

Sarısaman, Sadık: "Birinci Dünya Savaşı Sırasında İhtiyat Kuvveti Olarak Kurulan Osmanlı Genç Dernekleri”, OTAM, C.11 S.11, 2000, s. 439-501.

Thompson, Paul: "21. Yüzyılda Sözlü Tarih İçin Potansiyeller ve Meydan Okumalar", Kuşaklar, Deneyimler, Tanıklıklar, yay. haz. Aynur İlyasoğlu, Gülay Kayacan, İstanbul, Tarih Vakfi Yurt Yayınları, 2006, s. 23-37.

Toprak, Zafer: "İttihat ve Terakki’nin Paramiliter Gençlik Örgütleri”, Boğaziçi Üniversitesi Beşeri Bilimler Dergisi, C.VII, 1979, s. 95-113.

Türkiye Cumhuriyeti Maarifi 1923-1943, Ankara, Maarif Matbaası, 1944. 
Türkiye Cumhuriyeti Maarifi, 1940-1941, Ankara, Maarif Matbaası, 1941.

Ünal, M. Ezel: Gençler Silah Başına! Ders Kitapları Aracıllğıyla Türkiye’de Gençliğin Militarizasyonu (1926-1945), İstanbul, Galatasaray Üniversitesi, Sosyal Bilimler Enstitüsü, Yayımlanmamış Yüksek Lisans Tezi, 2014.

Vagst, Alfred: History of Militarism and Military, New York, The Free Press, 1967.

Yamak, Sanem: "Vatandaşlık Eğitimi ve Militer Eğitim", Tematik ve Kronolojik Türk Eğitim Tarihi, ed. Mustafa Gündüz, İstanbul, İdeal Kültür Yayıncılık, 2018, s. 307-340.

\section{Sözlü Tarih Görüşmeleri}

Mehmet Emin Altan ile yapılan görüşme, İstanbul, 11 Temmuz 2018.

Cahit Kayra ile yapılan görüşme, İstanbul, 19 Temmuz 2018.

Hıfzı Topuz ile yapılan görüşme, İstanbul, 26 Temmuz 2018.

Sttk1 Anadol ile yapılan görüşme, İstanbul, 14 Ağustos 2018.

Ziya Müezzinoğlu ile yapılan görüşme, İstanbul, 5 Eylül 2018.

Doğan Haşhaş ile yapılan görüsşme, İstanbul, 7 Eylül 2018.

Turgut Bulut ile yapılan görüşme, Bursa, 15 Eylül 2018.

Muharrem Özmelek ile yapılan görüşme, İstanbul, 24 Eylül 2018.

Orhan Yavuz ile yapılan görüşme, İstanbul, 10 Ekim 2018.

Ali Hüsrev Bozer ile yapılan görüşme, İstanbul, 14 Kasım 2018.

Özden İnönü Toker ile yapılan görüşme, Ankara, 17 Kasım 2018.

Özcan Köknel ile yapılan görüşme, İstanbul, 1 Aralık 2018.

Şazi Sirel ile yapılan görüşme, İstanbul, 8 Aralık 2018.

Ruhi Kafescioğlu ile yapılan görüşme, İstanbul, 10 Ocak 2019.

Ali İhsan Futacı ile yapılan görüşme, Bursa, 20 Nisan 2019.

Galip Uzunca ile yapılan görüşme, Bursa, 30 Ağustos 2019.

Rober Haddeciyan ile yapılan görüşme, İstanbul, 10 Eylül 2019.

Aram Kamburyan ile yapılan görüşme, İstanbul, 7 Kasım 2019.

Cemal Karabacak ile yapılan görüşme, İstanbul, 7Aralık 2019. 